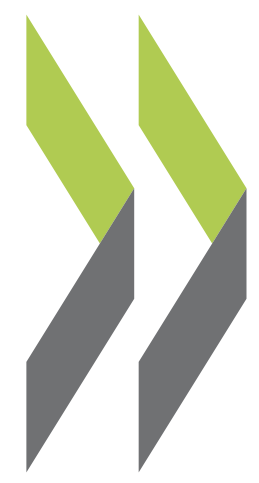

OECD Economics Department Working Papers No. 1254

Improving public sector efficiency for more inclusive growth in Latvia

Caroline Klein, Robert Price 
Organisation de Coopération et de Développement Économiques

Organisation for Economic Co-operation and Development

10-Aug-2015

ECONOMICS DEPARTMENT

English - Or. English

\section{IMPROVING PUBLIC SECTOR EFFICIENCY FOR MORE INCLUSIVE GROWTH IN LATVIA}

ECONOMICS DEPARTMENT WORKING PAPERS No. 1254

By Caroline Klein and Robert Price

OECD Working Papers should not be reported as representing the official views of the OECD or of its member countries. The opinions expressed and arguments employed are those of the author(s)

Authorised for publication by Robert Ford, Deputy Director, Country Studies Branch, Economics Department.

All Economics Department Working Papers are available at www.oecd.org/eco/workingpapers

JT03380740

Complete document available on OLIS in its original format

This document and any map included herein are without prejudice to the status of or sovereignty over any territory, to the delimitation of international frontiers and boundaries and to the name of any territory, city or area. 
OECD Working Papers should not be reported as representing the official views of the OECD or of its member countries. The opinions expressed and arguments employed are those of the author(s).

Working Papers describe preliminary results or research in progress by the author(s) and are published to stimulate discussion on a broad range of issues on which the OECD works.

Comments on Working Papers are welcomed, and may be sent to OECD Economics Department, 2 rue André-Pascal, 75775 Paris Cedex 16, France, or by e-mail to eco.contact@oecd.org.

All Economics Department Working Papers are available at www.oecd.org/eco/workingpapers.

This document and any map included herein are without prejudice to the status of or sovereignty over any territory, to the delimitation of international frontiers and boundaries and to the name of any territory, city or area.

The statistical data for Israel are supplied by and under the responsibility of the relevant Israeli authorities. The use of such data by the OECD is without prejudice to the status of the Golan Heights, East Jerusalem and Israeli settlements in the West Bank under the terms of international law.

(c) OECD (2015)

You can copy, download or print OECD content for your own use, and you can include excerpts from OECD publications, databases and multimedia products in your own documents, presentations, blogs, websites and teaching materials, provided that suitable acknowledgment of OECD as source and copyright owner is given. All requests for commercial use and translation rights should be submitted to rights@oecd.org 
ECO/WKP(2015)72

\section{ABSTRACT/RESUMÉ}

\section{IMPROVING PUBLIC SECTOR EFFICIENCY FOR MORE INCLUSIVE GROWTH IN LATVIA}

This working paper explores avenues to improve public sector efficiency in Latvia, a catching-up and ageing economy where spending needs are large. Ensuring that spending allocated to core services (e.g. education, healthcare) is adequate to achieve convergence of policy outcomes to OECD upper standards is challenging. Efficiency gains in the tax system could bring additional revenues. The tax base should be expanded by reducing informality, strengthening tax administration and increasing property and environmentally related taxes, which are low by international standards. To reduce unemployment and income inequality, the tax-benefit system should also be revised as it is now relatively regressive and the tax wedge on low-income earners is high. Enhancing analytical, monitoring and assessment capacities should help to rein in wasteful expenditure and improve the prioritisation of spending. The reform of human resource management, public procurement, and state-local relations is also needed to deliver higher-quality and more cost-efficient public services. This Working Paper relates to the 2015 OECD Economic Survey of Latvia (www.oecd.org/eco/surveys/economic-survey-latvia.htm).

Key words: Latvia, fiscal policy, budgetary framework, tax administration, public procurement, inequality, social benefits, grey economy

JEL Classification: E62, H2, H5, H6, H7, H83

\section{AMÉLIORER L'EFFICIENCE DU SECTEUR PUBLIC POUR UNE CROISSANCE PLUS INCLUSIVE EN LETTONIE}

Ce document de travail explore des pistes pour améliorer l'efficience du secteur public en Lettonie, une économie en rattrapage et vieillissante où les besoins de dépenses restent importants. L'enjeu va consister à assurer un niveau adéquat de dépenses consacrées aux services fondamentaux (éducation, santé) pour faire converger les résultats de l'action publique vers les normes les plus élevées de l'OCDE. Des gains d'efficience dans le système fiscal permettraient de collecter des recettes supplémentaires. On pourrait élargir la base d'imposition en réduisant l'activité informelle, en renforçant l'administration de l'impôt et en relevant les taxes immobilières et environnementales dont le niveau est faible par comparaison internationale. Pour abaisser le chômage et les inégalités de revenus, il faudrait aussi revoir le système de prélèvements et de prestations, car il est relativement régressif et le coin fiscal sur les personnes à faible revenu est important. Améliorer les capacités d'analyse, de contrôle et d'évaluation devrait contribuer à contenir les dépenses inutiles et à mieux hiérarchiser les priorités de dépenses. Une réforme de la gestion des ressources humaines, des marchés publics et les relations entre l'État et les collectivités locales s'impose également pour la fourniture de services publics de plus haute qualité et offrant un meilleur rapport coût-efficacité. Ce document de travail se rapporte à l'Étude économique de l'OCDE de 2015 sur la Lettonie. (www.oecd.org/fr/eco/etudes/etude-economique-lettonie.htm).

Mots-clés: Lettonie, politique budgétaire, cadre budgétaire, administration fiscale, marchés publics, inégalité, prestations sociales, économie souterraine

Classification JEL: E62, H2, H5, H6, H7, H83 


\section{TABLE OF CONTENTS}

Improving public sector efficiency for more inclusive growth in Latvia .....................................................

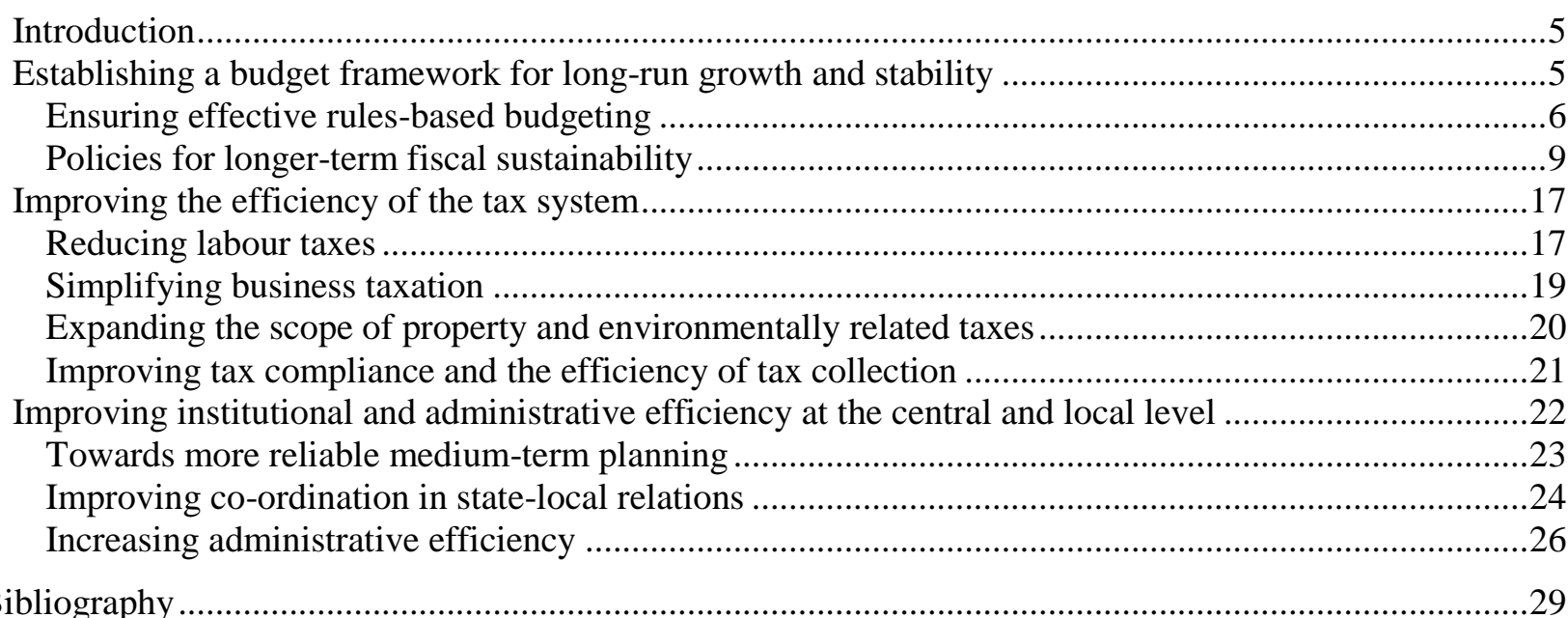

\section{Tables}

1. Components of public spending, 2012

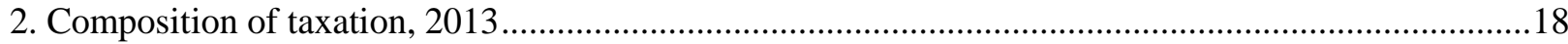

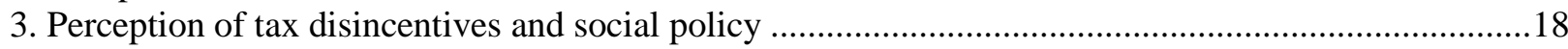

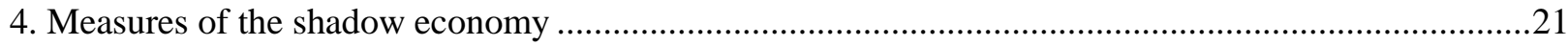

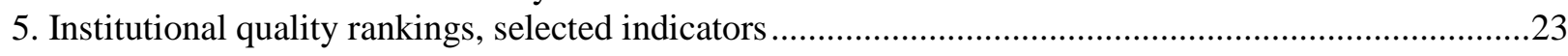

\section{Figures}

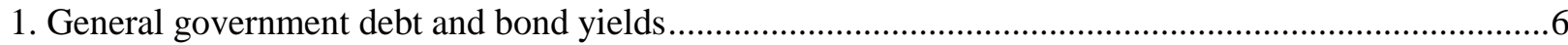

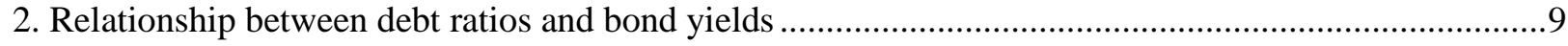

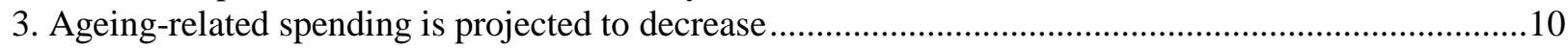

4. Public pension expenditure is set to decline significantly ................................................................11

5. Resource inputs and outcomes in the healthcare sector ....................................................................12

6. Educational outcomes and spending per student ….......................................................................13

7. Government investment accounts for a large share of public spending ...............................................14

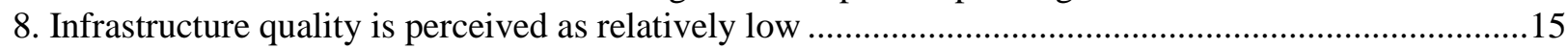

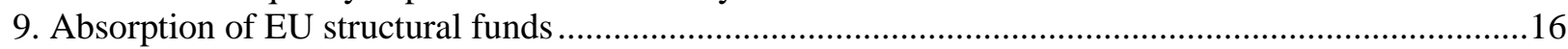

10. The tax burden is among the lowest compared with OECD countries ............................................17

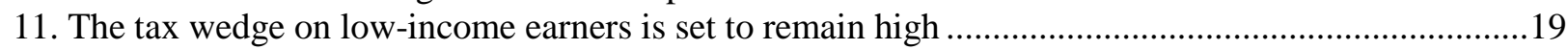

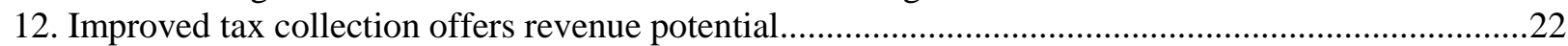

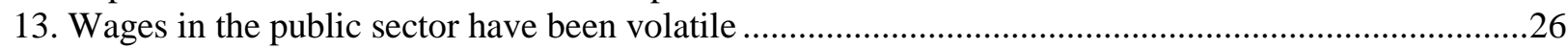

\section{Boxes}

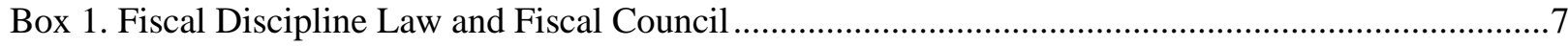

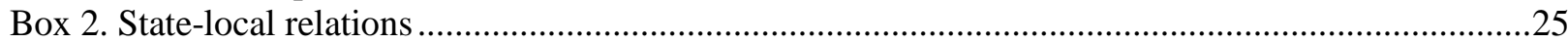

Recommendations to improve public sector efficiency ......................................................................28 
ECO/WKP(2015)72

\title{
IMPROVING PUBLIC SECTOR EFFICIENCY FOR MORE INCLUSIVE GROWTH IN LATVIA
}

\author{
By Caroline Klein and Robert Price ${ }^{1}$
}

\section{Introduction}

1. This working paper explores avenues for improving public sector efficiency in Latvia. Efficiency is broadly defined. There is a budgetary dimension, determined by the rules, planning processes and institutional framework necessary to achieve long-run growth and budget sustainability. The second element relates to output efficiency, which depends on the effectiveness of spending and programmes and taxation in achieving welfare (growth and distributional) objectives. The third element is cost efficiency, which relates to the management and organisation of expenditure programmes and tax systems, the latter including policies to combat the hidden economy. The budgetary framework conditions for long-run growth and fiscal sustainability are discussed in section I. Section II looks at the structure and administration of the tax system, in terms of the potential to reduce the inefficiencies caused by the tax composition and the need to improve tax collection processes. Section III discusses issues of institutional co-ordination, programme management and administration.

2. The main findings of the working paper are:

- The fiscal framework has been improved significantly and should ensure long-term sustainability of public finances. However, there is a risk that spending allocated to key public services (healthcare, poverty, infrastructure) will prove inadequate in view of desired outcome improvements.

- Addressing the high levels of inequality and informality is priority. Public spending should be better targeted at those more in need. The tax system should be made more progressive and the tax burden on labour reduced. Additional revenues should be raised by increasing property and environmentally related taxes. Strengthening actions against tax fraud is also crucial.

- The reliability and proficiency of the public sector can be improved by reinforcing strategic and monitoring capacities of in-charge institutions, by modernising human resource management, and by strengthening transparency in public procurement. Ensuring that local governments are sufficiently resourced and autonomous is also key to enhancing the quality of public services.

\section{Establishing a budget framework for long-run growth and stability}

3. Latvia has a stronger fiscal position than most OECD economies, the general government deficit being projected to gradually improve under current policies from around to slightly below $1 \%$ of GDP by 2017. The government debt ratio is one of the lowest in the OECD, at 38\% of GDP at the end of 2013 (Figure 1, Panel A), and bond yields are just above average levels in the European Union (EU) (Figure 1, Panel B). Even allowing for uncertainty about the rate of potential growth, such a low deficit should ensure

1. Caroline Klein is head of the Latvia/Denmark desk and Robert Price is consultant of the OECD Economics Department. This paper was originally published as part of the 2015 Economic Survey of Latvia under the authority of the Economic and Development Review Committee (EDRC). The authors would like to thank Robert Ford, Alvaro Pereira, Andreas Wörgötter, Zuzana Smidova, Herwig Immervoll, and Bert Brys for their useful comments, Corinne Chanteloup for statistical assistance and Heloise Wickramanayake for technical preparation. 
that without policy changes and further consolidation measures the debt ratio trends down for the rest of the decade to around 30\% of GDP. Nevertheless, future spending pressures will pose challenges to budget discipline.

\section{Ensuring effective rules-based budgeting}

4. Fiscal rules can contribute to that budget discipline. In the past, the fiscal framework in Latvia has lacked mechanisms to limit expenditure growth during cyclical upturns. Latvia ratified and fully implemented the Fiscal Compact through a Fiscal Discipline Law which entered into force in March 2013 (Box 1). The main principles of the Fiscal Discipline law are:

- A budget balance rule, which requires that the general government structural deficit shall not exceed $-0.5 \%$ of GDP.

- An automatic correction mechanism inspired by the Swiss debt break, which triggers an automatic improvement in structural balance if the cumulative deviation from the annual targets for the structural balance falls below $-0.5 \%$ of GDP.

- Medium-term expenditure ceilings and restrictions on net expenditure growth (deflated by the GDP deflator) are not to exceed average potential GDP growth.

\section{Figure 1. General government debt and bond yields}
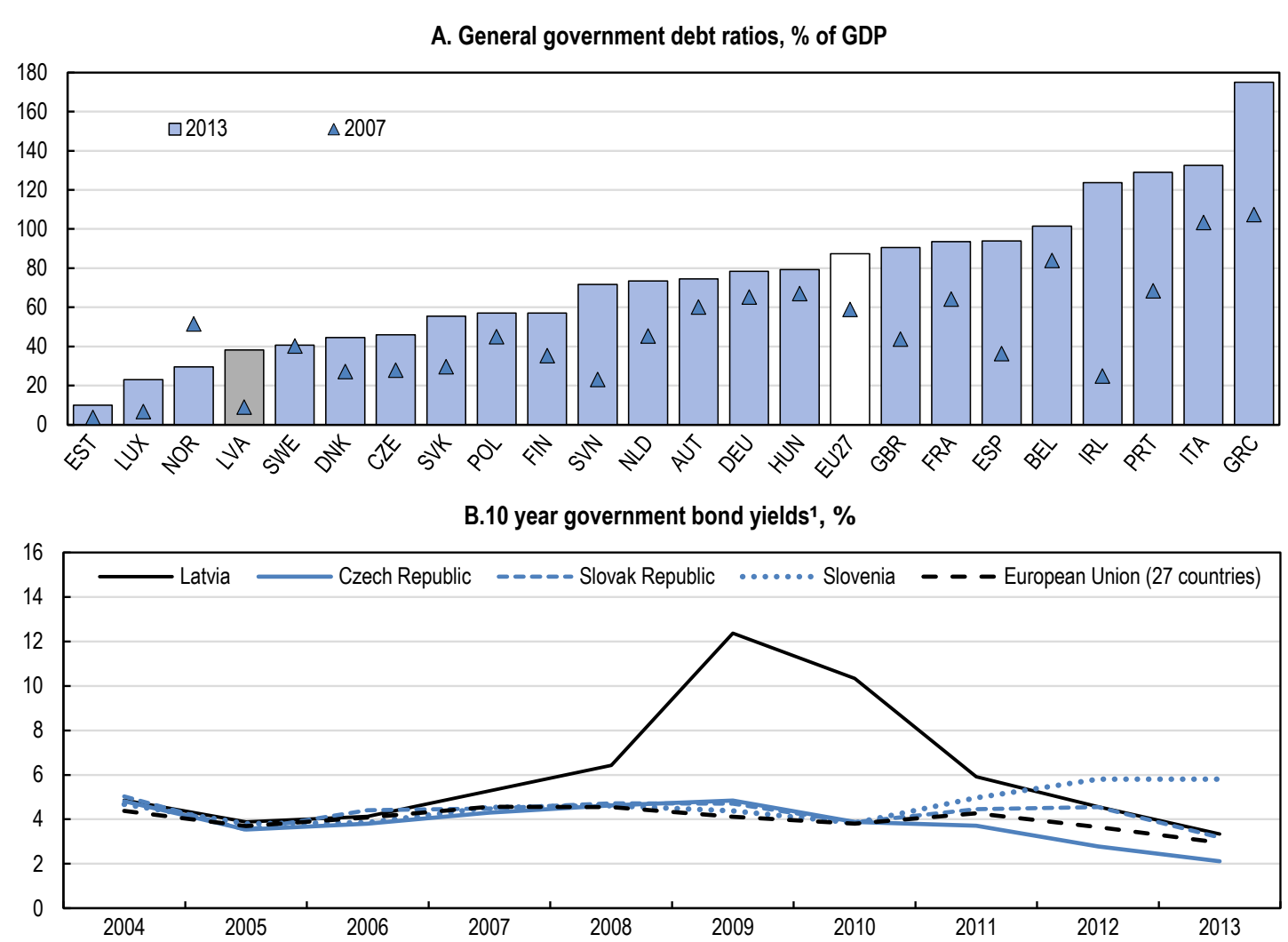

1. EMU convergence criterion bond yields.

Source: Eurostat database. 
5. The annual Medium-Term Budgetary Framework Draft Law defines maximum permissible spending by setting the general government structural budget balance in accordance with the structural balance rule and determining expenditure growth consistent with the defined structural balance and the expenditure growth rule.

6. The Fiscal Council, established on 1 January 2014, oversees the implementation of fiscal rules (Box 1). This independent institution reports annually to the Parliament about the consistency of the Medium-Term Budgetary Framework Draft Law and the Annual State Budget Draft law with the fiscal rules. If any breach is observed, it issues a report including recommendations to address the identified deviations. The council is a key institution for achieving transparency and is a safeguard against political pressures undermining the credibility of fiscal rules. At the same time, its effectiveness is reinforced by the fiscal rules, which are designed to prevent medium-term deviations from programmed expenditure paths. In Latvia a programme-based budget format with a three-year perspective has been applied since the 2008 budget, but before 2013 the framework only indicated the ceilings of the State budget for total central government expenditure over the medium term. The new system embeds the annual budget process in a broader three-year framework with ceilings for line ministries which have a legally binding force.

\section{Box 1. Fiscal Discipline Law and Fiscal Council}

The Fiscal Discipline Law stipulates the underlying principles of sound budget practice: the efficient use of available resources; the counter-cyclicality of fiscal policy; the pursuit of economic growth and financial stability; the maintenance of a sustainable general government debt level; inter-generational mutual responsibility; inter-governmental solidarity, and transparency.

\section{Fiscal Rules}

The Law stipulates that the general government structural balance in the Medium-Term Budgetary Framework Draft Law shall not be lower than -0.5 percentage of GDP. In the event of significant deviation from the national medium-term objective, it provides for an automatic adjustment mechanism, which registers deviations of the actual structural balance (+/-) from its planned targets in a specific notional account. If the cumulative deviation is negative and higher than $0.5 \%$ of GDP, a correction is triggered automatically by improving structural balance in the next Medium-Term Budgetary Framework Draft Law by an extra $0.5 \%$ until deviation is fully compensated. In addition, the Law stipulates that draft laws submitted to the Parliament and legislation adopted by the Cabinet (with some exceptions) which breach the budget expenditure ceiling or reduce state budget revenues need to be compensated by equivalent expenditure or revenue adjustments elsewhere.

\section{The Fiscal Council}

The Fiscal Discipline Council was established on 1 January, 2014 and consists of six members of which three are nominated under the joint proposal of the Governor of the Bank of Latvia and the Minister of Finance and three by the Parliament. Members cannot be re-elected more than twice consecutively. The Council performs regular monitoring of compliance with the requirements of the Fiscal Discipline Law and prepares an annual report which is submitted to the Parliament together with the Medium-Term Budgetary Framework Draft Law. The Council is also required to prepare an Irregularity Report if any violation of the Fiscal Discipline Law is discovered. The first report was issued in March 2014, relating to the draft amendments to the State Pension Law.

\section{Sanctions}

The Stability and Growth Pact stipulates that non-compliance with either the preventive or corrective arms of the Pact can lead to the imposition of sanctions. In the case of the corrective arm, this can involve annual fines for the euro area member states and, for all countries, possible suspension of Cohesion Fund financing until the excessive deficit is corrected. 


\section{Stabilisation Reserve}

The Long-Term Stabilisation Reserve Law, in force since May, 2014, stipulates that government budget surpluses should be accumulated in a reserve account, for use in the event of financing difficulties. Financial resources that are allocated to the reserve cannot be used for financing budgetary needs (e.g. new policy initiatives and other priority measures), or to pay down debt. Accumulated funds will ensure that the country has resources to fund itself if it is impacted by a significant and unexpected adverse event or does not have access to financial resources at a sustainable price. Currently, no resources have been accumulated in the reserve and no assessment of its optimal size has been carried out.

7. A combination of a budget balance objective and medium-term expenditure ceilings is acknowledged as best practice from a political economy point of view and most effective in locking in consolidation gains (Price, 2010). Framing the rule in terms of structural balance, rather than actual balance, ensures the operation of the automatic stabilisers, thereby reducing the risks of discretionary policy intervention. However, the last decade has demonstrated accurate calculation of output gaps and structural deficits is difficult, raising the possibility that under some circumstances budgets will prove unintentionally pro-cyclical.

8. The low debt level - which stands well below the Maastricht ceiling - does not offer Latvia extra fiscal flexibility, since it has relatively higher debt-financing rates compared to OECD countries with similar debt levels (Figure 2) and during extreme turbulences borrowing at reasonable costs may be restricted. With the accession in the euro area, Latvia can benefit from the European Stability Mechanism, a permanent crisis resolution mechanism, which can issue loans and other forms of financial assistance to euro area countries in or threatened by severe liquidity problems. Also, the establishment of a banking union should limit the impact of banking crisis on public finances. The Single Resolution Mechanism (SRM) backed by a Single Resolution Fund introduced resolution tools that involve private bank investors and the banking sector as a whole in covering bank losses before involving public finances (OECD, 2014a).

9. There is, nevertheless, scope to build-up additional fiscal liquidity buffers over time, not least because Latvia's exposure to external shocks is higher than in the average EU country. The Fiscal Discipline Law introduced two counter-cyclical reserves. The first, the Long-Term Stabilisation Reserve, is set to accumulate government budget surpluses, i.e. saving in good times in order to soften budget constraints in bad times, but no resources have actually been accumulated yet. The second, the Fiscal Security Reserve, has been established to mitigate the negative impact of smaller adverse macroeconomic developments on the budget and fiscal risks (e.g. risks related to loans repayments, loan guarantees, publicprivate partnerships). The size of this reserve is set annually and should not fall below $0.1 \%$ of GDP from 2017 onward.

10. There is a question mark over the long-term optimality of the public debt profile: there is no official debt target, but the long-run debt ratio implied by a structural deficit of $0.5 \%$ would be $10 \%$ of GDP or below (depending on the long-run growth rate), which would be very low for a catching-up economy. To ensure robust convergence, such economies need to invest relatively more in growthenhancing areas (e.g. infrastructure, education, health). As experience with the new fiscal framework accumulates, the authorities may wish to adjust fiscal rules to permit more debt financing of needed investment expenditures, though the settings of the rules will always have to conform to EU fiscal requirements. 
Figure 2. Relationship between debt ratios and bond yields

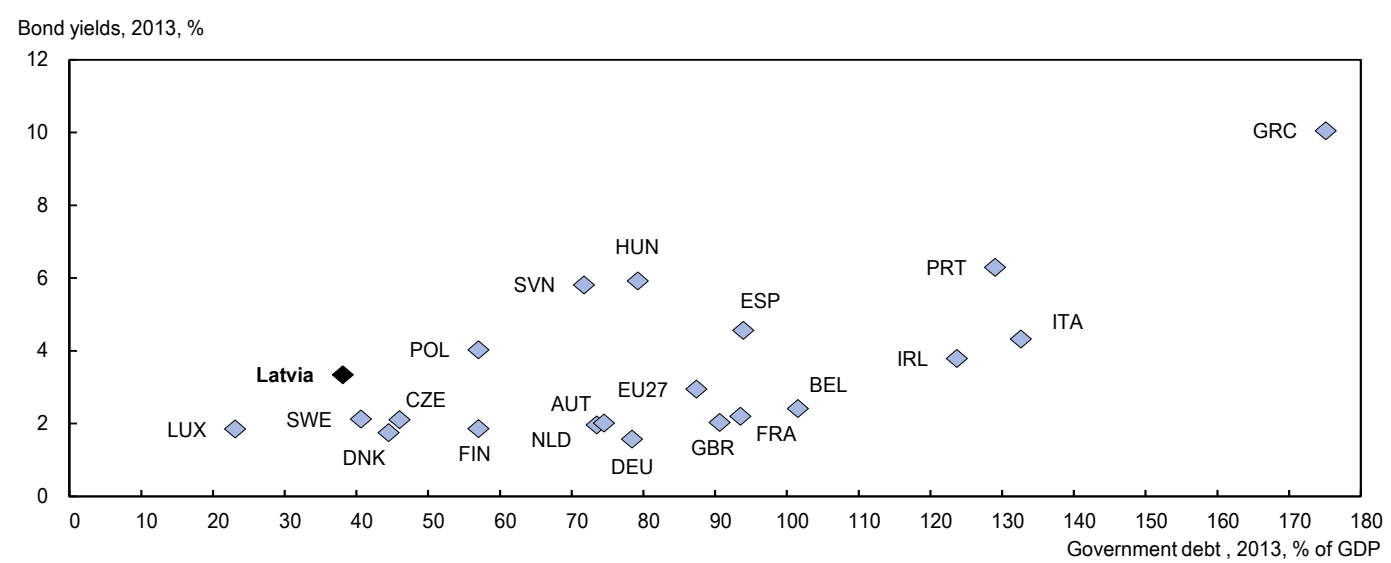

Source: Eurostat database.

\section{Policies for longer-term fiscal sustainability}

11. Latvia appears to be in a better position than most OECD economies to meet future demographic challenges, and hence to ensure long-run fiscal sustainability, notably because commitments to pension and healthcare recipients are lower. Latvia currently allocates a significantly smaller proportion of GDP to the public sector than the European OECD countries (respectively $36.5 \%$ and $45.6 \%$ in 2012) and, within this total, the composition of public spending differs from the average largely with respect to the smaller proportion of GDP spent on social protection and health (Table 1). The problem is that health, poverty and inequality outcomes currently are relatively low, suggesting that associated spending is insufficient (World Bank, 2014). The prospective convergence in GDP levels would be expected to reduce the differences between Latvia and the OECD-average outcomes. But an issue arises as to whether the current long-run sustainability assumptions are compatible with a full convergence of health and social outcomes.

Table 1. Components of public spending, 2012

\begin{tabular}{|c|c|c|c|c|c|c|}
\hline & $\begin{array}{c}\text { General public } \\
\text { services }\end{array}$ & $\begin{array}{c}\text { Economic } \\
\text { affairs }\end{array}$ & Health & Education & $\begin{array}{c}\text { Social } \\
\text { protection }\end{array}$ & Other $^{3}$ \\
\hline \multicolumn{7}{|c|}{ Percentage of total } \\
\hline Latvia & 12.3 & 14.5 & 10.7 & 15.1 & 30.7 & 16.7 \\
\hline Peers $^{1}$ & 12.0 & 10.3 & 15.4 & 12.6 & 33.8 & 16.0 \\
\hline OECD Europe ${ }^{2}$ & 14.1 & 9.5 & 14.1 & 11.9 & 38.1 & 12.2 \\
\hline \multicolumn{7}{|c|}{ Percentage of GDP } \\
\hline Latvia & 4.5 & 5.3 & 3.9 & 5.5 & 11.2 & 6.1 \\
\hline Peers $^{1}$ & 5.1 & 4.4 & 6.5 & 5.4 & 14.4 & 6.8 \\
\hline OECD Europe ${ }^{2}$ & 6.8 & 4.6 & 6.8 & 5.7 & 18.3 & 5.8 \\
\hline
\end{tabular}

1. "Peers" is an average of Czech Republic, Estonia, Slovenia, and Slovak Republic.

2. OECD Europe includes all European OECD countries, except Turkey.

3. "Others" includes defence, public order and safety, environmental protection, housing community amenities, recreation, culture and religion.

Source: Eurostat. 
12. On the basis of underlying demographic projections and policy parameters, Latvia's long-term age-related liabilities seem to be contained relative to the OECD average, with age-related public spending projected to decrease in the period 2010 to 2060 by almost 31/2 per cent of GDP (Figures 3 and 4). These projections assume, however, that the private sector will take on greater responsibility for pension and health provision and that the efficiency of health and education provisions will increase. Past pension reforms imply a long-term fall in spending (Figure 4). The planned decline in the replacement ratio of the notional defined contribution public pension system (from $48 \%$ to 15\%) more than offsets the projected increase in the dependency ratio (European Commission, 2012). The statutory pension age is being increased from 62 to 65 years between 2014 and 2025 and mandatory contributions to the funded pension scheme are being increased gradually from $2 \%$ of gross wages to $6 \%$ in 2016 . However, the combined scheme amounts to very low pension payments. The total replacement rate is set to remain among the lowest in the EU at $43.6 \%$. This carries a long-term risk that the adequacy of future pensions would need to be revised and pensions made more generous.

13. Latvia's expenditure on social assistance may also be unsustainably low, non-contributory social assistance programmes accounting for only about one fifth of total social protection spending (World Bank 2014a). Social assistance is mostly delivered in the form of cash transfers rather than targeted on the basis of need, and is largely composed of universal family and child allowances. Conversely, poverty-targeted programmes represent only $10 \%$ of the total spending on social assistance which is relatively low. Even after its recent expansion, expenditure on the Guaranteed Minimum Income (GMI) program, which is the main poverty-targeted program in the country, remains very moderate compared to other EU countries (0.16\% of GDP in 2011). The distributional impact of the tax system is among the lowest in the EU (BICEPS, 2014) probably due to the universal, untargeted nature of the benefit system and the effectiveness of policies in reducing poverty and inequality is perceived as ineffective (WEF, 2014). This suggests the need for better targeting universal social benefits at low-income households. Inequality tends to be higher in economies on a fast catch-up path, where opportunities for high income are a key incentive for investors and entrepreneurs to achieve the necessary upgrading of the economy, but Latvia's level of income inequality is high even by the standards of other countries at the same level of economic development. To the extent that the benefits system as a whole is not sufficient to have a meaningful impact on poverty and inequality, the catching up process could bring the need for resources allocated to this sector to be increased.

Figure 3. Ageing-related spending is projected to decrease

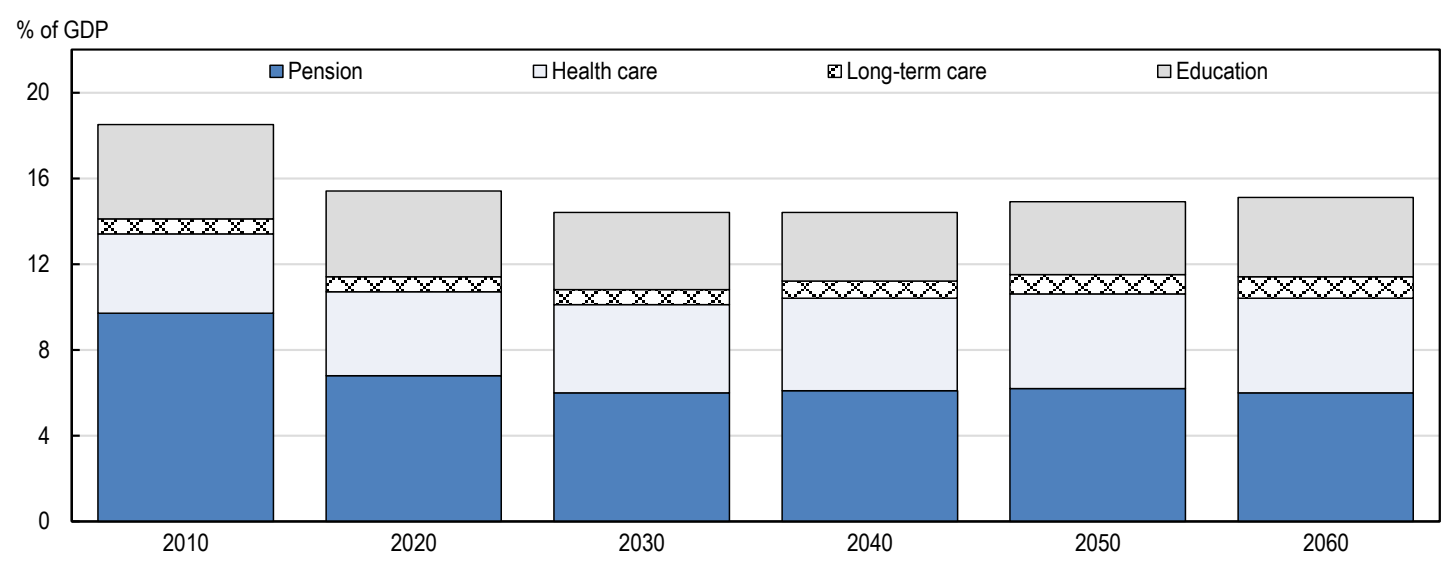

Source: European Commission (2012); Government of Latvia (2013). 
Figure 4. Public pension expenditure is set to decline significantly

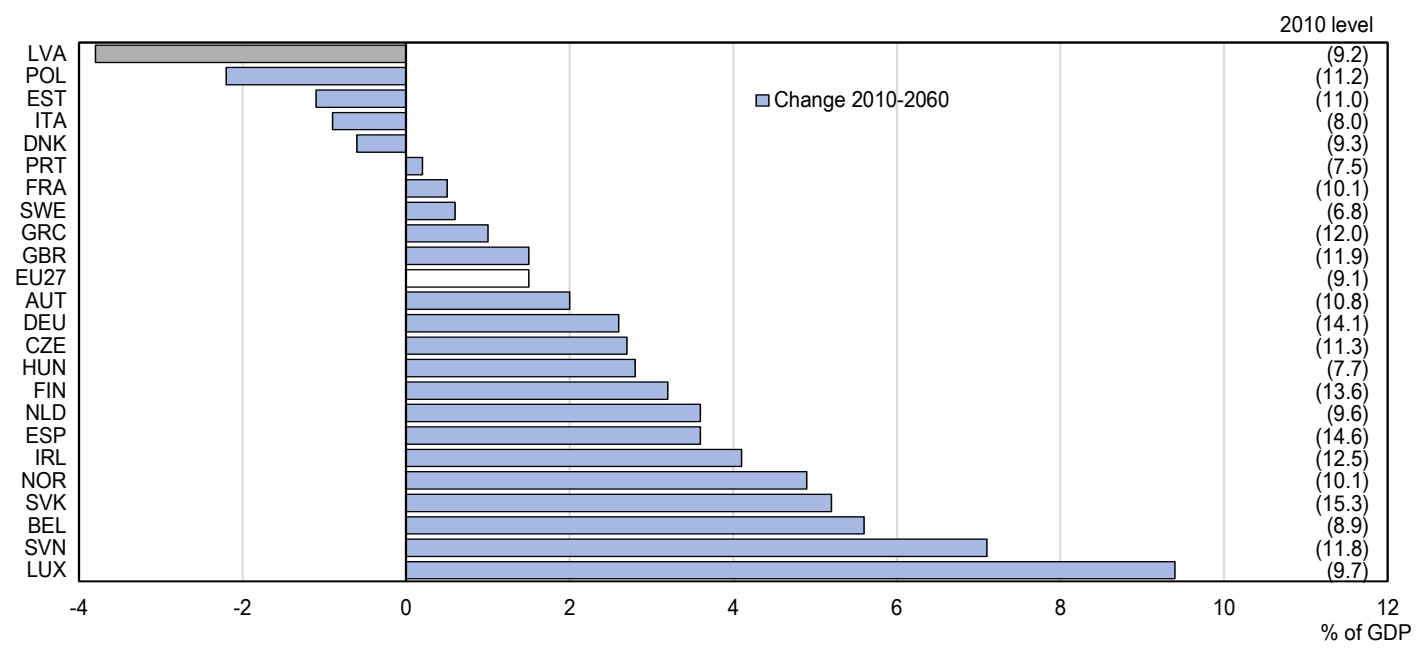

Source: European Commission (2012); Government of Latvia (2013).

\section{The need to resource health spending}

14. Total healthcare spending amounts to 6\% of GDP and is well below the OECD average of around $9 \%$ of GDP. Of this, only $3.8 \%$ of GDP is public spending, the rest being private out-of-pocket payments. Demographics are expected to push public spending to around 4.5\% of GDP by 2060 (see Figure 3). Currently, life expectancy is also among the lowest in the European OECD countries, reflecting a low level of spending (Figure 5, Panel A). Mortality rates for men, women and infants are higher than in most other EU countries. According to European Commission survey data, $66 \%$ of citizens evaluate the overall quality of health care as bad (2011), and 65\% believe that the quality of care in Latvia is worse than in other EU member states (2010). The Euro Health Consumer Index 2012 puts Latvia near the bottom of its ranking index.

15. The economic crisis, having resulted in a decrease in financial resources for health care, created a new impetus for structural reforms aimed at reducing costs. As a result, the allocation of resources among different providers is improving - shifting from expensive hospital care to less costly ambulatory care, and putting a higher priority on primary care (WHO and EOHSP, 2012). However, the large co-payment presents barriers to lower-income groups. Financial constraints focus public monies on the provision of emergency care, creating long waiting times for other care.

16. There is substantial scope to improve cost efficiency, reduce waiting lists, give more attention to chronic conditions and focus more on preventable lifestyle diseases. Latvia should continue to catch up with average OECD performance in terms of health outcomes. However, although only a small increase in public healthcare resources ( $0.6 \%$ of GDP) has been factored into long-run fiscal sustainability calculations, the planned improvement in outcomes - life expectancy is projected to increase by more than 10 years up to 2060 - exceeds the achievements in any other OECD member country for the same prospective level of public inputs (see Figure 5, Panel B). The share of resources allocated to health care are thus likely to be inadequate, as pointed out in the 2012 Health System Review (WHO and EOHSP, 2012). The implication is that health spending may need to rise by more than allowed for in the long-run fiscal sustainability scenario. Private co-payments could increase, but that could exacerbate current health coverage problems. Reforms are envisaged to link health entitlements to those who regularly pay income tax and socially vulnerable people, whom the state will insure. Convergence in health outcomes could well 
need an increase in the public health spending/GDP ratio beyond that provided for, again requiring increased tax revenues.

Figure 5. Resource inputs and outcomes in the healthcare sector

A. 2012

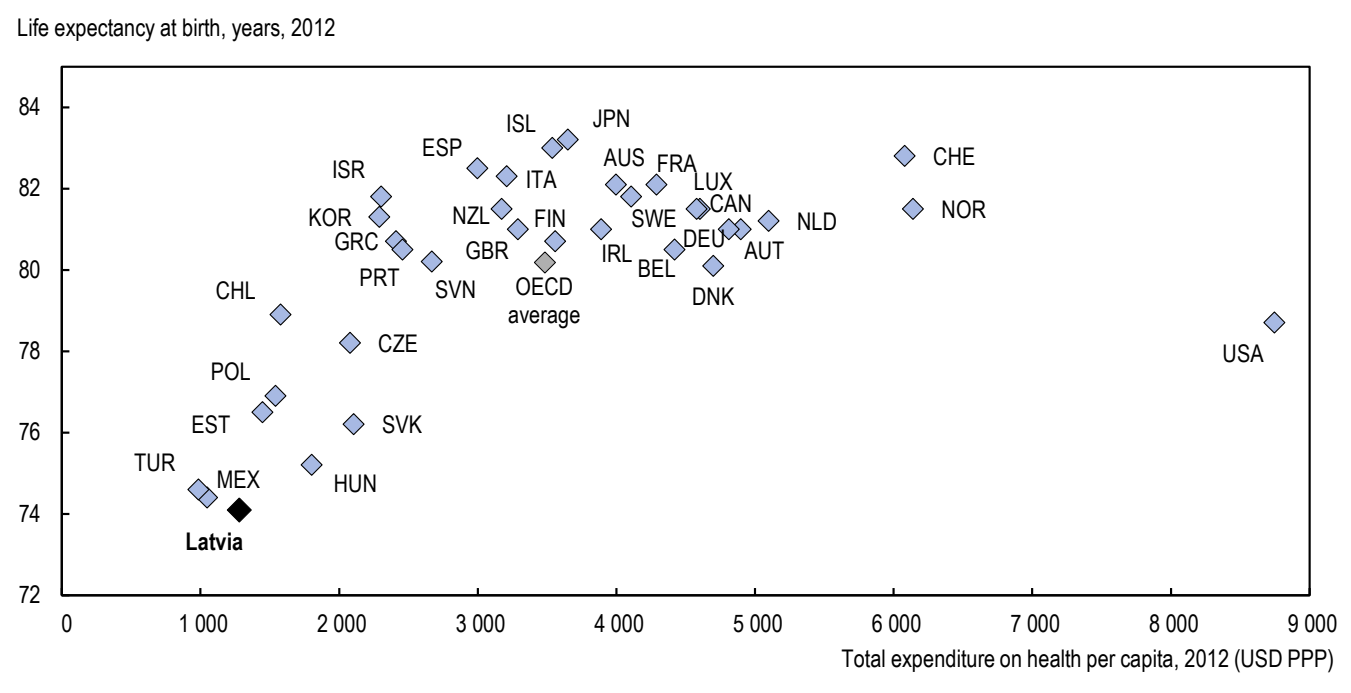

B. 2060

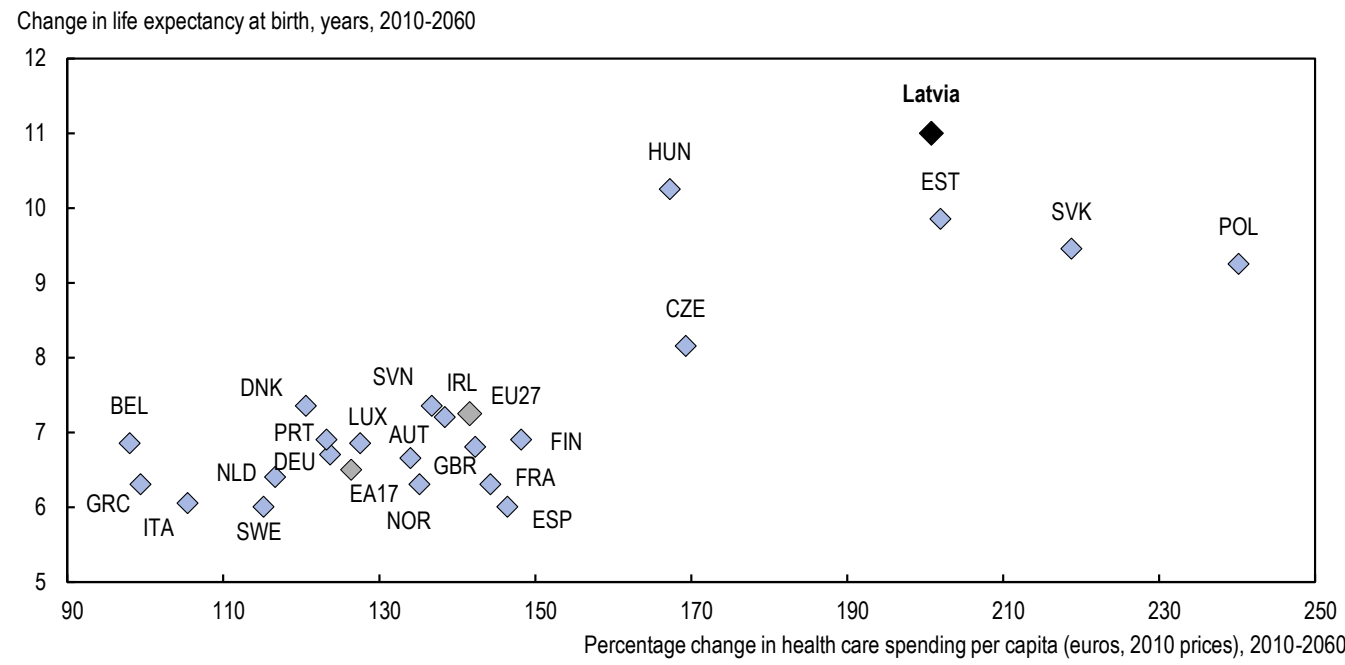

Source: OECD Health Statistics, World Development Indicators database, Eurostat database and European Commission (2012), "The 2012 Ageing Report".

\section{Meeting education requirements}

17. Public education expenditure, benefiting from demographic trends, is projected to decline from 4.4\% of GDP to 3.5\% of GDP by 2050 (European Commission, 2012). Up to the secondary level, Latvia's educational performance, as measured by PISA scores, is slightly above average for the resources committed (Figure 6). Efficiency savings in the education system, such as increases in the teacher to student ratio, have been part of the recent budgetary consolidation. Funding allocation is now tied to pupil enrolment, which has resulted in consolidation and efficiency gains, but also to unequal access and uneven quality, the latter being associated both with demographic changes and staffing problems inherited from the Soviet era (Terauda et al., 2014). Efforts to improve educational quality need to build on the 
attractiveness of educational careers, strengthening the links between teacher pay and performance (Sutherland et al., 2007 and OECD, 2014).

Figure 6. Educational outcomes and spending per student

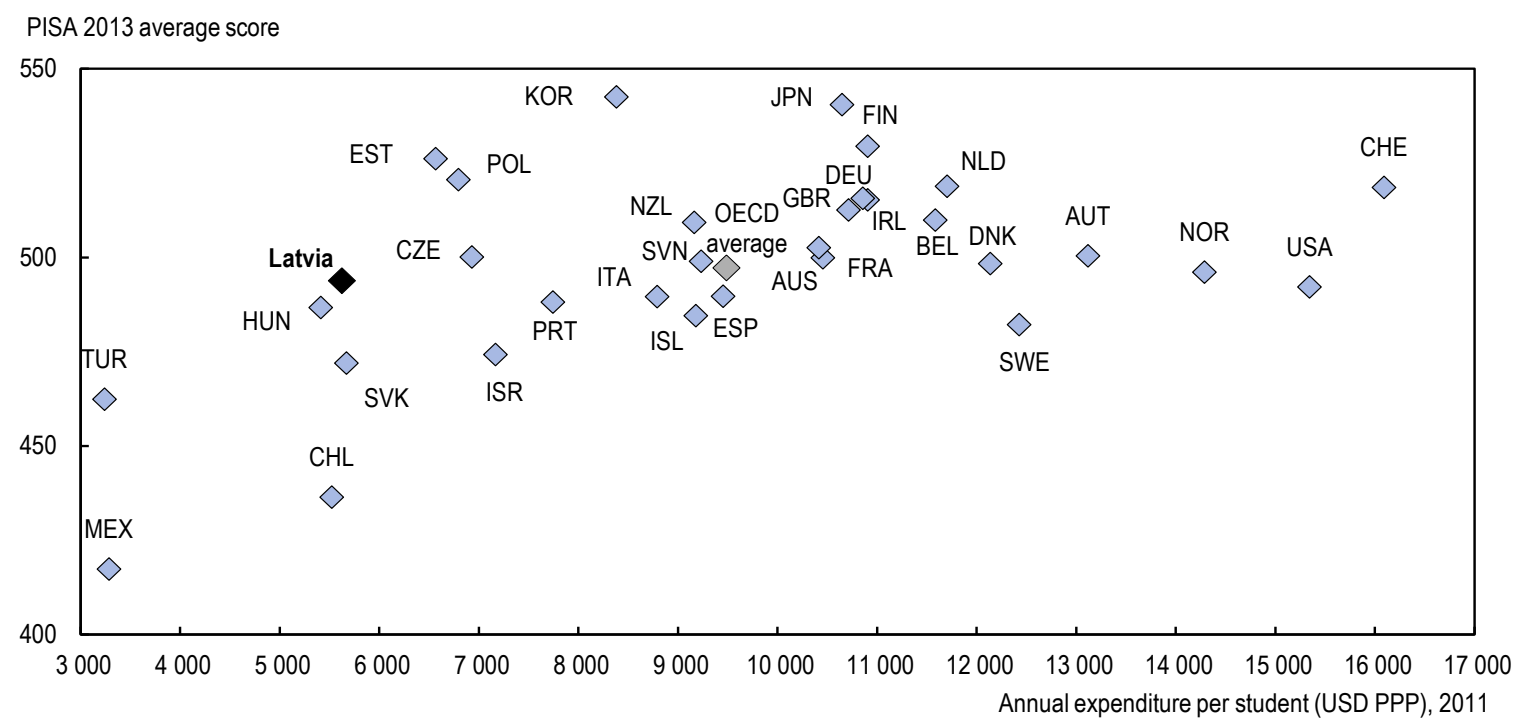

Source: OECD, PISA 2012 Database and OECD (2014), Education at a glance, table B1.1a.

18. Latvia is currently performing less well in vocational and higher education. To date, the VET has not had a particularly good image; the share of those who consider that VET provides high-quality learning was well below the EU average (Eurobarometer, 2011). Survey evidence shows that employers believe vocational education institutions are failing to supply students with the skills needed on the labour market. The policy aim is to increase the quality of vocational education to ensure it meets the requirements of market, while promoting a more efficient use of available resources, notably by optimising and differentiating the number and location of vocational education and improving infrastructure in vocational education institutions with the support of the European Regional Development Fund.

19. Higher education also needs modernising. At the tertiary level, Latvia reached the EU 2020 educational target of $40 \%$ of 30- to 34-year-olds having university-level qualifications in 2013, from a ratio of $26 \%$ in 2009. Nevertheless, the higher education system is dominated by social sciences, where there are too many institutions given the population, which results in low entrance requirements and thinly distributed academic resources (Terauda et al., 2014).

20. Longer-run efficiency gains depend closely on the success of structural reforms, inter alia, by implementing a new financing model that rewards quality, strengthens links with market needs and research institutions, and avoids fragmentation of budget resources. This would have efficiency benefits in terms of outcomes as well as better match of skills to labour market requirements. However, these reforms might be difficult to implement. Reform attempts undertaken between 2011 and 2013 have been met with substantial resistance from educational institutions themselves.

\section{Ensuring adequate public investment}

21. Public investment accounts for a relatively high share of government spending (Figure 7) although it has been significantly cut in the 2009-12 period (Traidase, 2014). Over the medium term, the 
proportion of investment in public spending and GDP will have to increase, since public investment is needed to maintain convergence. However, allocating sufficient resources to public investment under the fiscal rules is challenging and might require increasing tax revenues. In the meantime, though, Latvia should make the most of the resources at its disposal, which involves the effective use of EU structural funds, and resort to private finance where there is the possibility of effectively using public-private partnerships (PPPs).

Figure 7. Government investment accounts for a large share of public spending

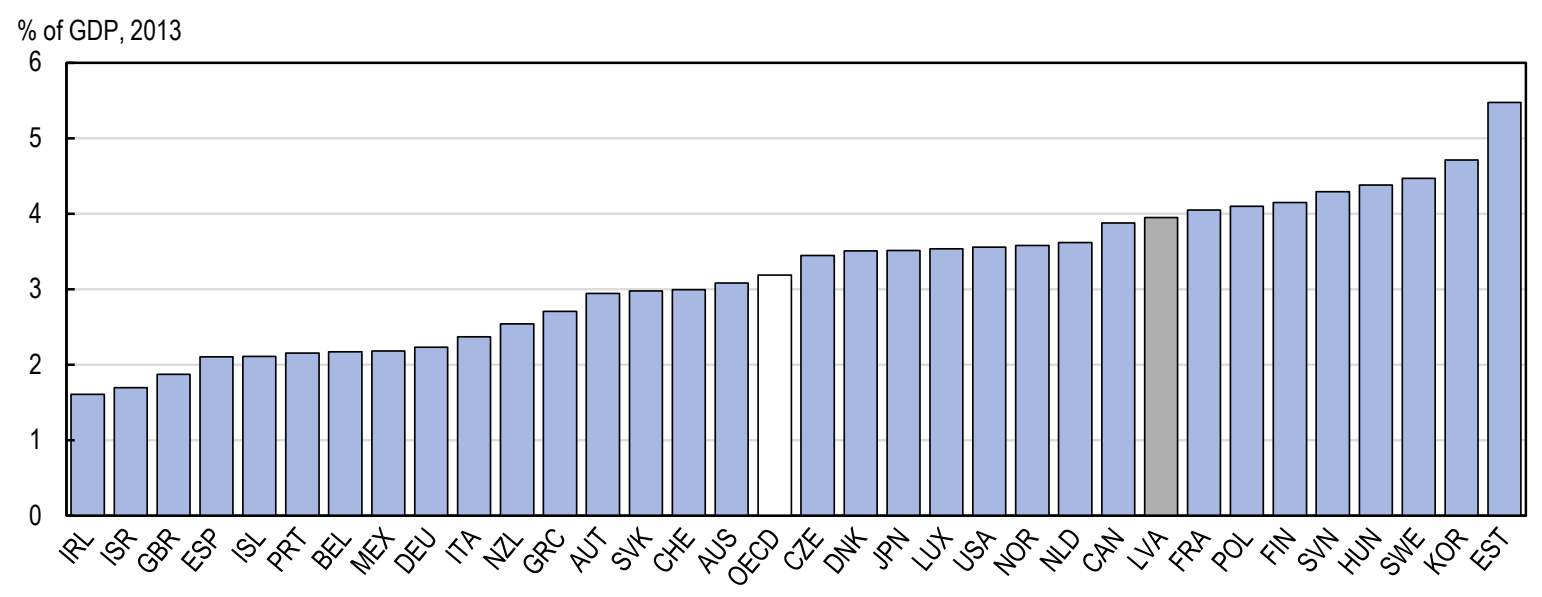

Source: OECD Economic Outlook 96 database.

22. The amount of public funding provided for R\&D is the lowest of any EU member state and the lack of public funding is identified by the Ministry of Education as a major factor slowing down scientific progress in the country. Expenditure for scientific research in the business sector in 2010 was $0.22 \%$ of GDP, placing Latvia significantly below the average EU-27 rate of $1.23 \%$ of GDP. Annual fluctuations in funding for research institutions produce uncertainty, inducing young scientists to look for opportunities abroad. There is a persistent lack of state funds for participation in international research and infrastructure projects. The Innovation Union Scoreboard study ranks Latvia second to last in terms of innovation performance among 27 surveyed EU countries (European Commission, 2014b). Designing and implementing an effective research and innovation policy which upgrades infrastructure and rationalises research institutions while encouraging companies to innovate is likely to have additional resource implications.

23. Public infrastructure is one of the most important public contributors to a favourable business environment and hence to growth potential. Considerable resources are required in this respect. The overall quality of logistical infrastructure in Latvia is perceived as relatively low (Figure 8, Panel A). The main problem is road infrastructure. Even though a large number of important roads cross Latvia, they suffer from insufficient investment in maintenance and construction. Data from Latvian State Roads show that more than $50 \%$ of roads and bridges are in bad or very bad condition, and that there are almost no roads that are of high quality throughout their entire length. The Global Competitiveness Index also suggests that roads in Latvia are the worst of all Central and Eastern European (CEE) countries except Poland (WEF, 2014a). Moreover, the perceived quality of Latvian roads decreased between 2005 and 2010, while it increased in Lithuania and Estonia. 
Figure 8. Infrastructure quality is perceived as relatively low

Global Competitiveness Index, score (1-7 scale)

A. Quality of overall infrastructure ${ }^{1}$

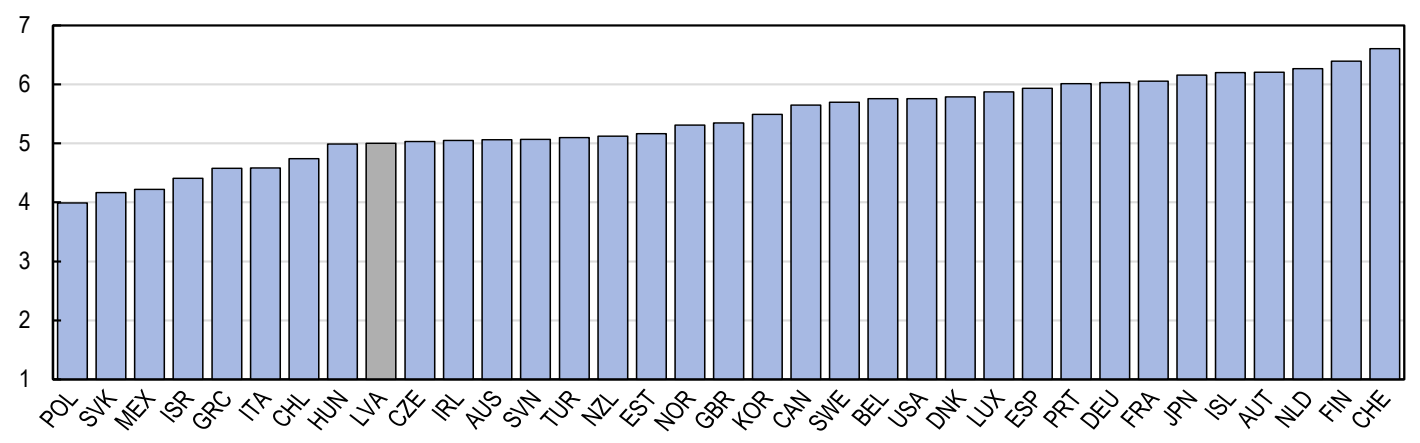

B. Quality of roads ${ }^{2}$

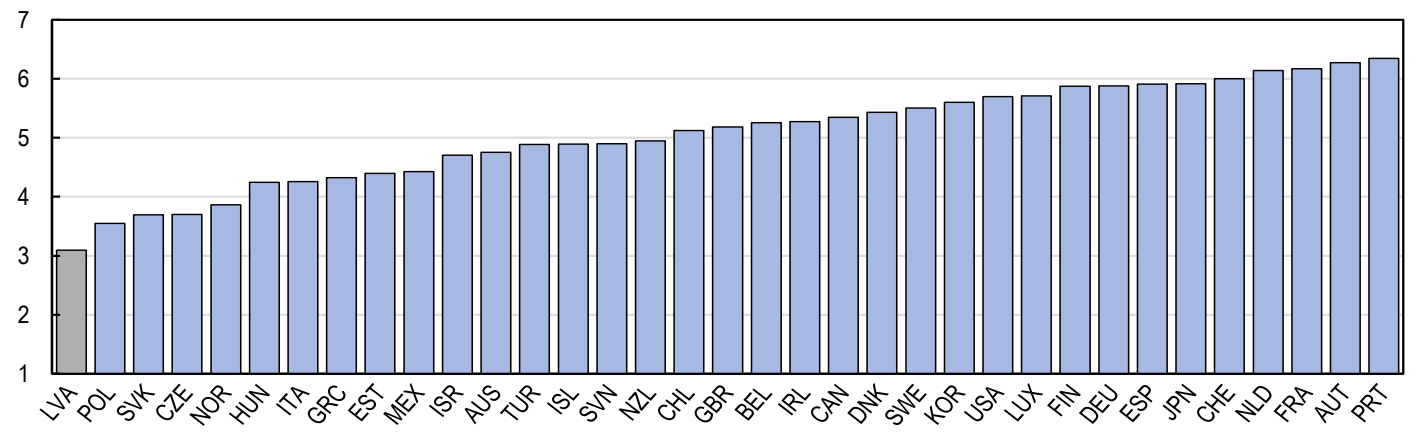

1. The responses are to the question: "How would you assess general infrastructure (e.g., transport, telephony, and energy) in your country? [ 1 = extremely underdeveloped—among the worst in the world; 7 = extensive and efficient-among the best in the world]".

2. The responses are to the question: "In your country, how would you assess the quality of roads? [1= extremely underdeveloped—among the worst in the world; 7 = extensive and efficient—among the best in the world]".

Source: The Global Competitiveness Index Historical Dataset, 2005-2014 World Economic Forum.

\section{Using EU structural funds effectively}

24. The EU structural funds have been an important funding source, in particular during the global financial crisis. Funding covers infrastructure, human capital, R\&D, ICT and technical assistance. It is not used to finance stand-alone projects, but rather is based on operational programmes managed and implemented by the national authorities. In the 2007-2013 programming period, Latvia was one of the largest structural fund recipients (Figure 9, Panel A). For the next programming period (2014-2020), similar amounts are allocated (EUR 4.51 billion, i.e. around $2.8 \%$ of GDP per year). Projects are always co-financed by the national budget and therefore depend on the availability of national resources and institutional governance structures for implementation. Latvia has managed these challenges relatively well (Katsarova, 2013 and Figure 9, Panel B). Nevertheless, a new legislation has been adopted, which clarifies the division of responsibilities of the various managing authorities. In particular, it is planned to ease the procedure for evaluating draft submissions, which will be approved only by the Supervisory Committee of the EU Funds, without the need for additional Cabinet approval. Also, a clear procedure is being laid down for the settlement of disputes and a one-stop agency principle applied in order to reduce the administrative burden on funding recipients and submitters of projects. 
Figure 9. Absorption of EU structural funds

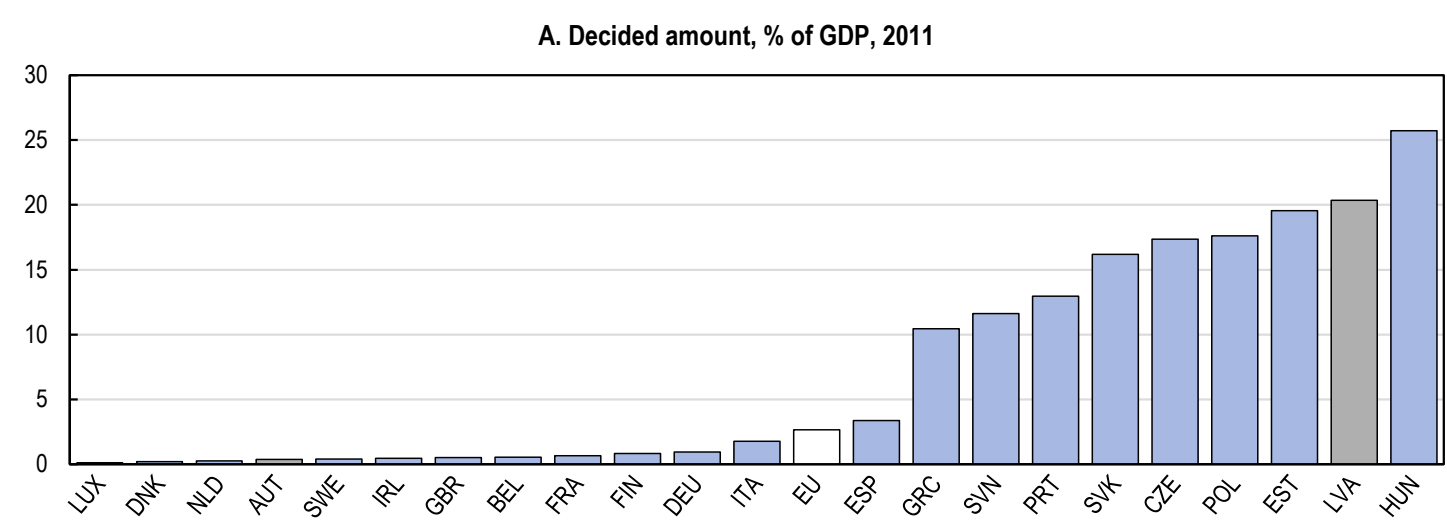

B. Absorption rate of EU funds, expenditure paid and claimed, \% of decided amount, 2012

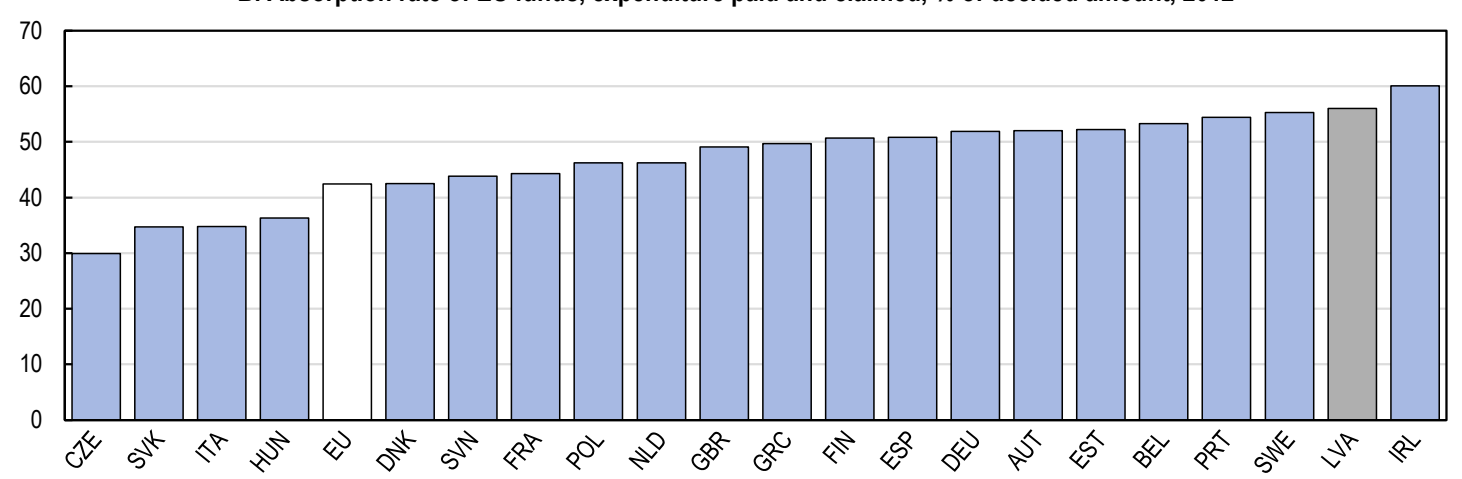

Source: European Commission.

\section{Extending the role of private finance}

25. PPPs could also be used to fund public infrastructure. They have been actively promoted in Latvia since 2004. In 2005 a "Policy Framework for Promotion of Public-Private Partnerships" identified number of loopholes including the inadequacy of the legal framework with EU standards, a lack of institutional co-ordination, a disconnection between PPPs and public investment planning, and a lack of tools available to ministries to support PPP evaluation (Ministry of Finance, 2014). The Latvia Investment and Development Agency (LIDA) also started the preparatory work on five PPP pilot projects to create a template for good practice and evaluate possible obstacles in PPP implementation. On the basis of the pilot projects and the obstacles identified, a new Law on PPP was adopted in 2009. To further promote the use of PPPs, the government has established an inter-ministerial action plan and working group, generating scope for co-operation between the Baltic States (Ministry of Finance, 2014).

26. The governance of PPP poses challenges, however, as some EU countries discovered in the wake of the global financial crisis. In particular, projects financed by PPP should be subject to the same costbenefit analyses as those that would be financed by the budget. In addition, the present and future cost of the PPPs should be transparently accounted for in the budget documents. Experience from other countries indicates that $i$ ) a prudent and rigorous approach to Value For Money assessment, ii) a track record of successfully implemented projects, iii) a credible pipeline of future projects and $i v$ ) international assurance as to the quality, reliability and capacity of public administration and institutions, are essential ingredients for the PPP model to be sustained and developed. These are all elements on which the Latvian authorities will need to maintain their focus into the medium term. 


\section{Improving the efficiency of the tax system}

27. Latvia has the competitive advantage of having one of the lowest tax-to-GDP ratios in the EU, at $28 \%$ of GDP (Figure 10). However, the overall low tax burden conceals a number of structural distortions which inhibit employment growth and reduce revenue efficiency by driving activity underground. The main challenge facing tax policy is to break the link between high marginal rates on labour activity and the erosion of the tax base; the one now reinforces the other. Also, given the current and future spending pressures, improving efficiency in the tax system is crucial. The two instruments for achieving this are shift in marginal income tax rates away from rate-sensitive labour income and improved tax compliance. Tackling these distortions would raise revenues by expanding the tax base, while supporting economic growth and reducing inequality.

Figure 10. The tax burden is among the lowest compared with OECD countries

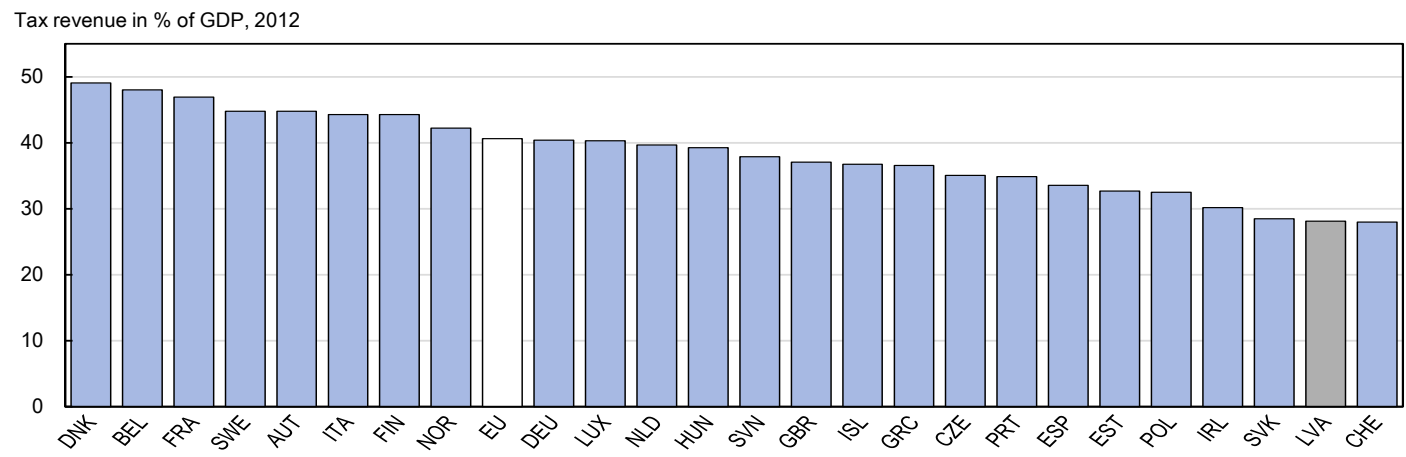

Source: Eurostat.

\section{Reducing labour taxes}

28. The composition of taxes is skewed towards the taxation of labour, the combination of income tax and social security contributions accounting for 53\% of total revenues (as opposed to $50 \%$ in the OECD area) (Table 2). The labour income tax burden is relatively high, averaging 50\% of earnings (vs. $40 \%$ in the EU). In January 2014, the combined employer and employee social security contribution rate was reduced by one percentage point to $34.09 \%$ but remains high by international standards. 
Table 2. Composition of taxation, 2013

\begin{tabular}{|c|c|c|c|}
\hline & OECD & Latvia & Difference \\
\hline Personal income tax & 24.1 & 20.1 & -4.0 \\
\hline Corporate income tax & 8.7 & 5.5 & -3.2 \\
\hline Social security contributions & 26.2 & 32.9 & 6.7 \\
\hline Payroll taxes & 1.1 & - & -1.1 \\
\hline Property taxes & 5.4 & 2.6 & -2.8 \\
\hline General consumption taxes & 20.3 & 25.2 & 4.9 \\
\hline Specific consumption taxes & 10.7 & 11.0 & 0.3 \\
\hline $\begin{array}{l}\text { Other taxes }{ }^{1} \\
\text { Total }\end{array}$ & $\begin{array}{c}3.4 \\
100.0\end{array}$ & $\begin{array}{c}2.7 \\
100.0\end{array}$ & $\begin{array}{l}-0.7 \\
\mathbf{0 . 0}\end{array}$ \\
\hline
\end{tabular}

1. Including certain taxes on goods and services (heading 5200) and stamp taxes.

Source: OECD Revenue Statistics, Ministry of Finance

29. Moreover, the tax wedge for low-income earners is one of the highest in the OECD (Figure 11). This contributes to the low employment rate of 51\% among the low-skilled, which is below the EU average and almost 35 percentage points lower than that of high skilled workers, which, at $85 \%$, exceeds the EU average. The elasticity of demand and supply of labour with respect to wages is generally higher for lower-income workers, so these disincentives impinge especially on them. Labour taxes are also perceived as having important disincentives to work, or conversely to participate, in the formal economy in Latvia (Table 3). To the extent that high tax rates are regressive and are both a deterrent to labour market participation (contributing to the large hidden economy via a "participation tax rate") and to formal employment, economic efficiency and equity would be improved by concentrating tax reduction efforts on low-income groups.

Table 3. Perception of tax disincentives and social policy

Global and Europe 2020 Competitiveness Indexes, score (1-7 scale)

\begin{tabular}{lccccc}
\hline & Latvia & Lithuania & Estonia & $\begin{array}{c}\text { Slovak } \\
\text { republic }\end{array}$ & $\begin{array}{c}\text { Czech } \\
\text { Republic }\end{array}$ \\
\hline Extent of taxation on incentives to invest $^{1}$ & 3.8 & 3.1 & 4.9 & 3.2 & 3.3 \\
${\text { Extent of taxation on incentives to } \text { work }^{2}}^{\text {Social safety net protection }}{ }^{3}$ & 3.3 & 2.9 & 4.3 & 2.9 & 3.1 \\
$\begin{array}{l}\text { Government effectiveness in reducing poverty and } \\
\text { inequality }^{4}\end{array}$ & 3.8 & 3.6 & 4.1 & 3.8 & 4.4 \\
\hline
\end{tabular}

Notes: Scores based on the answer to the following questions: $1 /$ In your country, to what extent do taxes reduce the incentive to invest? [1=significantly reduce the incentive to invest; $7=$ do not reduce the incentive to invest at all] $2 /$ In your country, to what extent do taxes reduce the incentive to work? [1=significantly reduce the incentive to work; $7=$ do not reduce incentive to work at all] $3 /$ In your country, to what extent does a formal social safety net provide protection from economic insecurity in the event of job loss or disability? ( $1=$ not at all; 7 = provides full protection). $4 /$ In your country, how effective are the government's efforts to address income inequality? ( 1 = not effective at all; 7 = extremely effective)

Source: World Economic Forum, Global competitiveness Report, 2014 -2015 and Europe 2020 competitiveness Report, 2014

30. Latvia has already begun to reduce taxes on labour and further steps in this direction are planned by 2016. A tax allowance for dependants was increased in 2014 and the personal income tax rate is to be gradually decreased, by one percentage point annually to $22 \%$ in 2016 . A ceiling on the base for social security contributions was reintroduced in 2014. According to recent OECD estimates, the recent and planned measures will not reduce significantly the tax wedge of low-paid workers which is set to remain above the OECD average (Figure 11). Reducing the social security contribution rates on low wages would have a higher impact, even if large cuts in these rates would be needed to reduce the tax wedge to the OECD average level (Figure 11). 
31. One option to further reduce the labour tax wedge is to cut social security contributions on low wages. Such a policy has been implemented in 14 OECD countries with generally a positive impact on the employment of low-skilled workers (OECD, 2011a). To avoid increases in the share of low paid jobs and associated deadweight costs, the decrease could be targeted at particular low-income groups (such as young workers, long-term unemployed, first-time job applicants) and tax enforcement should be strengthened. The reduction in the social security contribution rate should not lead to a reduction of social coverage (e.g. pension replacement rates) which, as noted above, is low by international standards. Another possibility, already on the agenda of the authorities, is to increase the personal income tax allowance, phased out for higher incomes.

32. A carefully designed and integrated tax and transfer reform will also be important to ensure that effective marginal tax rates are low for those transitioning into employment. In Latvia, the financial gain from moving into work is particularly low for low-income earners because of the way means-tested benefits are withdrawn as income rises (BICEPS, 2014). The planned gradual withdrawal of certain social benefits (guaranteed minimum income and housing benefit) is welcome and would significantly reduce the marginal effective tax rates for those taking a low paid job. Given the widespread underreporting of salaries (Putnins and Sauka, 2014), this measure needs to be coupled with further actions against undeclared work.

Figure 11. The tax wedge on low-income earners is set to remain high

Minimum Wage, single person without children, \% of total labour compensation, 2013

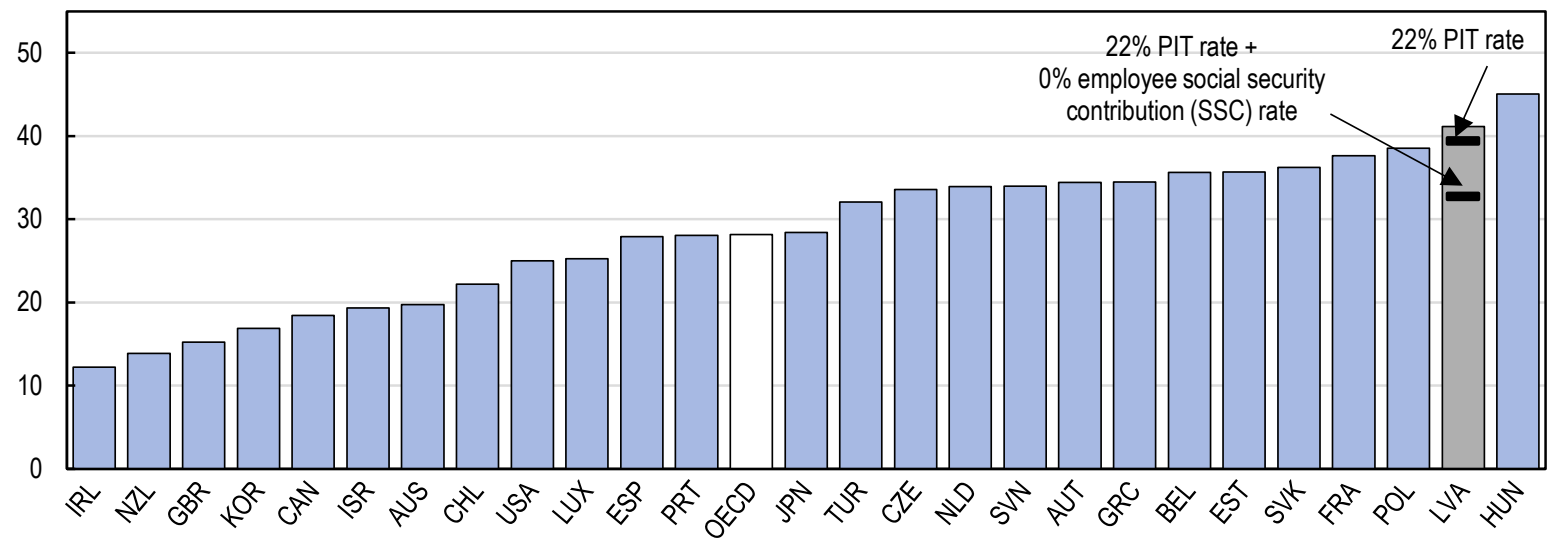

Note: The figure shows the impact on the tax wedge for a single person without children of planned reform of the personal income taxation (PIT) in 2016, i.e. the reduction of the PIT tax rate to $22 \%$, and of this reform combined with social security contribution paid by employees set to zero.

Source: OECD Tax-Benefit Models (2013 provisional).

\section{Simplifying business taxation}

33. Corporate income tax and property tax constitute a much smaller proportion of the total tax take than the OECD average (see Table 2). Nevertheless, surveys record a negative impact of taxation on investment (Table 3) which might be due to the administrative burden of compliance. Paying tax involves a low number of payments ( 7 per year vs. 13 on average in the EU). The time firms spend complying with tax legislation in Latvia has been significantly reduced over the past few years mainly thanks to the introduction of an electronic declaration system and a simplified declaration filling process. Nevertheless, it remains higher than in the EU on average (193 hours vs. 176 hours) and in regional peers ( 81 hours in 
Estonia, 175 hours in Lithuania, PWC and World Bank, 2014). Over complication, which are likely to be associated with larger informal sectors, more corruption and less investment, should be removed.

\section{Expanding the scope of property and environmentally related taxes}

34. The proportion of property taxes in overall taxation, at $2.6 \%$, is around a half of the OECD average, with revenues from the taxation of land and buildings amounting to only $0.8 \%$ of GDP in 2013 (see Table 2). Coverage of the property tax has recently been increased and since early 2013 local governments have some flexibility in choosing appropriate tax rates within a pre-defined bracket of 0.2$3 \%$. However, the municipalities have been reluctant to increase property taxes as they compete for taxpayers.

35. There is no clear model for property taxation to be copied from OECD countries: cross-country variation in property tax collection is substantial and variation actually increases sharply with national income level (Norregaard, 2013). Nevertheless, property taxes are widely regarded as an efficient and equitable means of raising revenue. Its potential for maintaining overall revenues in the face of necessary cuts in the tax burden on labour should be exploited. A property tax reform would by itself not have a significant effect on poverty and inequality but could be an important facilitator of poverty-reducing reform, depending on its design. Substantial property tax reform would raise important political economy problems, as in many other OECD economies. In this light, it is difficult to be precise about how much a 'realistic' reform of property taxes could raise. According to recent estimates, doubling the residential and land tax rates could increase revenues by EUR 100 million, i.e. $0.4 \%$ of GDP (BICEPS, 2014).

36. There is scope for better pricing environmental externalities. The indicators relating to waste management and air quality suggest that the taxation rates in place may not be conducive enough to environmentally friendly behaviour. $84 \%$ of municipal waste is landfilled two and a half times more than the EU average. Newly registered passenger cars in Latvia have the highest $\mathrm{CO}_{2}$ emissions per kilometre in the EU (Dreblow et al., 2013) and high levels of particulate matter (PM10) have been recorded along some busy roads in Riga (European Commission, 2014).

37. Environmental taxation has been recently extended. In 2010, a registration tax for passenger cars differentiated by $\mathrm{CO}_{2}$ emission per $\mathrm{km}$ and an annual tax on vehicles depending on the engine capacity and volume were introduced. This has led to a decrease in the average emissions of new cars but would be more efficient if it applied to all vehicles. A new road toll tax (the so-called euro vignette) for trucks using the highways was also created in July 2014. In addition, the tax rates on landfilling construction, industrial, and municipal waste were increased (for municipal waste from $1.78 \mathrm{EUR} /$ tonne in 2009 to $12 \mathrm{EUR} /$ tonne in 2015).

38. Nevertheless, the implicit tax rate on energy - measuring energy taxation per unit of energy - is among the lowest in the EU. Fuel taxes do not reflect their relative negative impact on the environment. Furthermore, there are tax exemptions or reductions on the use of fuels in agriculture, for heat generation and heating energy. An $80 \%$ VAT tax deduction is applied to corporate passenger cars, which are often used for private purposes, on both purchase price and operating costs (e.g. fuel; Lamine and Lohmuste, 2014). A wider application of environmentally related taxes, including pollution and energy sources, as well as a progressive increase of the existing landfill tax, would help achieve environmental goals, while allowing taxation to be shifted away from low-income earners. In particular, the fuel tax rates should be increased and set at a rate that better reflects their carbon content, while environmentally harmful subsidies should be phased out. 


\section{Improving tax compliance and the efficiency of tax collection}

39. The shadow economy is relatively large. Estimates of unreported activity are inherently difficult to make and tend to vary depending on the source and the method used, but according to survey evidence, the informal economy accounts for around 24\% of GDP, 8-9 percentage points higher than in Estonia or Lithuania (Putnins and Sauka, 2014). Schneider (2013) also finds that Latvia has one of the largest informal economies among EU countries, amounting to around $25.5 \%$ of GDP. Behind this aggregate figure, the degree of underreporting of business profits and salaries ("envelope" wages) is particularly marked, being approximately twice as large as the underreporting of the number of employees, while bribes constitute approximately $10 \%$ of firms' revenue (Table 4). According to surveys, the tolerance of tax evasion is more entrenched in Latvia than in Estonia or Lithuania and firms are more dissatisfied with the tax system and the government, which is a factor behind high informality (Putnins and Sauka, 2014).

Table 4. Measures of the shadow economy

\begin{tabular}{ccccc}
\hline & Business profits & Number of employees & Salaries & Level of bribery \\
\hline & (\% of actual profits) & (\% of actual employees) & (\% of actual salaries) & $\begin{array}{c}\text { (\% of revenue spent on } \\
\text { payments 'to get things done') }\end{array}$ \\
\hline Estonia & 10.3 & 8.1 & 17.1 & 4.7 \\
Lithuania & 11.8 & 6.4 & 15.5 & 10.3 \\
Latvia & $\mathbf{1 9 . 9}$ & $\mathbf{1 0 . 3}$ & $\mathbf{2 5 . 2}$ & $\mathbf{1 0 . 5}$ \\
\hline
\end{tabular}

Source: Putnins J. and A. Sauka, (2014)

40. The high level of informality reduces tax collection efficiency. Correcting poor tax compliance is important, as it leads to resource misallocation, by diverting resources into unproductive uses and reducing the transparency needed for the efficient functioning of capital markets. It can also have severe budget effects, eroding the tax and social security bases, causing increases in tax rates and/or budget deficits, while distorting official statistics such as GDP, which are important signals to policy makers. Finally, it excludes part of the population from the social security system, contributing to the high level of inequality and increasing the poverty risks.

41. The VAT compliance gap, the difference between the amount of VAT effectively collected and the amount theoretically due, increased substantially during the crisis, leaving the country with one of the highest registered gaps in the EU (3.5\% of GDP, Figure 12). Measures to increase revenues were taken during the crisis, when the standard VAT rate was increased from $18 \%$ to $22 \%$, the reduced rate rose from $5 \%$ to $12 \%$, and the scope of its application was narrowed. However, these crisis-related rate increases were not reflected in VAT revenues or in the implicit tax rate on consumption. The compliance gap could be due to fraud, delayed payments, collection of past debts, changes in refund patterns, underreporting, or failure to register. While it is difficult to determine how best to cope with the problem and how to assess the effectiveness of the tax administration, the indication is that the efficiency of the VAT system has been greatly affected by the economic crisis and there is significant scope for improvement as the economy recovers, in particular if supported by policy action to improve tax collection. 
Figure 12. Improved tax collection offers revenue potential

2012, VAT gap 1 \% of GDP

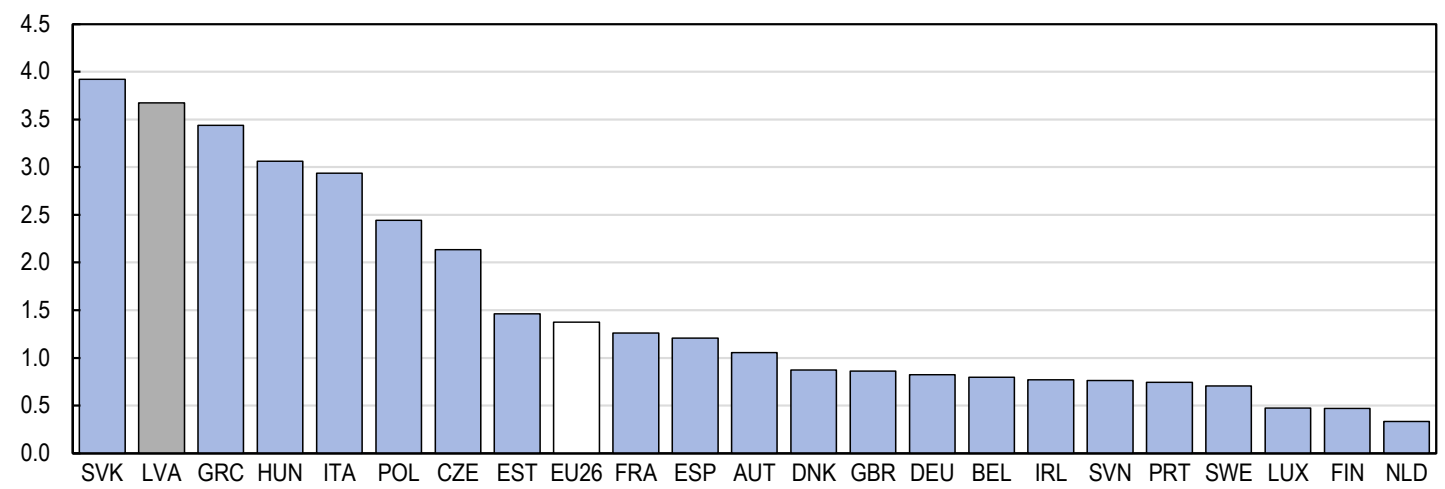

1. The VAT Gap is the difference between the VAT Collections (as recorded by Eurostat) and the amount theoretically due, i.e. VTTL (VAT Total Tax Liability). The latter is the total amount of estimated VAT payments on the basis of national accounts aggregates and the existing structure of rates and exemptions.

Source: European Commission (2014c), "2012 Update Report to the Study to quantify and analyse the VAT Gap in the EU-27 Member States", September 2014 and Eurostat database.

42. Tackling the problem of tax non-compliance requires a broad-based approach to reduce the administrative burden, ensure the efficient operation of controlling authorities, impose sanctions and support honest businesses. In 2010, an "Action Plan to Combat Shadow Economy and Promote Fair Competition in 2010 - 2013" was prepared, which encompassed a wide range of measures, including, for example, the proscription of cash transactions in wholesale trade and improved registration procedures for businesses. In parallel, several policy decisions have been or are being adopted in order to reduce the stock of tax arrears and to limit their accumulation in the future. The Strategy of the State Revenue Service 20142016 sets a strategic target of simplifying existing services, improving the range of electronic services and simplifying the tax and customs fees payment process. Greater emphasis on facilitation should help taxpayers to fulfil their obligations, including those who have accumulated tax debts, while heavier penalties should help deter deliberate tax evasion.

43. There is, however, a question mark as to whether sufficient resources are being allocated to fight tax fraud. The State Revenue Service of Latvia (SRS) is an integrated state governmental institution responsible for tax, excise and customs administration, including crime detection and prevention in tax and customs area. One of the targets set in the Strategy of SRS for 2014-2016 is "to increase the efficiency and effectiveness of using the SRS's resources". However SRS plans to meet this target without increasing the number of staff. Moreover, the allocated resources for salaries would not seem sufficient and may not ensure that salaries are competitive or staff sufficiently motivated. SRS staff turnover is on a growing trend and staffing is a problem especially for auditors, investigators, lawyers - key positions for tackling tax fraud. Without the allocation of additional resources, the foreseen improvement in revenue collection for the period 2013-2016 is in danger of not being achieved.

\section{Improving institutional and administrative efficiency at the central and local level}

44. Overall, Latvia has a well-structured budgetary framework but ranks poorly on the WEF Global Competitiveness scale for political institutions and governance, with opinions about the wastefulness of government spending being particularly poor (Table 5). Given the need to increase the amount of resources committed to the core public programmes discussed above, an essential part of the policy response thus needs to be on improving the allocative and cost efficiency of public spending, which demands an analysis 
of efficiency at three levels: $i$ ) planning and prioritisation of spending, ii) coordination between levels of government, iii) programme management.

Table 5. Institutional quality rankings, selected indicators

\begin{tabular}{lcccc}
\hline & Latvia & Lithuania & Estonia & Russia \\
\hline Social Infrastructure and Political Institutions (SIPI) & 57 & 48 & 27 & 86 \\
Political institutions & 87 & 61 & 24 & 91 \\
Public trust of politicians & 99 & 92 & 37 & 57 \\
\hline Wastefulness of government spending & 97 & 88 & 33 & 65 \\
Favouritism in decisions of officials & 72 & 44 & 26 & 79 \\
Rule of law & 54 & 47 & 27 & 100 \\
\hline Ethical behaviour of firms & 78 & 61 & 30 & 94 \\
\hline Control of Corruption (WB) & 43 & 46 & 29 & 108 \\
\hline
\end{tabular}

Note: Ranking over 151 countries. Source: The Global Competitiveness Index Historical Dataset, 2005-2014, World Economic Forum

\section{Towards more reliable medium-term planning}

\section{Ensuring effective prioritisation}

45. During boom years, budgeting involved in-year adjustments with at least one supplementary budget and additional expenditures each year (Kraan et al., 2009). In part, this has been due to the instability of governments and the availability of additional cyclical revenues. Medium-term budgeting coupled with a target for the budget balance could correct this deficiency. The new budget system includes multi-annual estimates of spending at the line-item level. This can help to better prioritise spending. This medium-term approach should also be an effective means to avoid pro-cyclical and wasteful spending. However, current medium-term expenditure plans assume the discontinuation of a wide range of existing programmes and do not take fully into account the cost of measures that are envisaged for the next three years (e.g. expanding the social benefit system, reforming the healthcare sector). This undermines the credibility of the medium-term budget and increases the risk of underestimating future spending needs.

\section{Improving strategic capacity}

46. Strategic capacity has also been improved with the establishment of a new central-government planning unit, the Cross-Sectoral Coordination Centre (PKC). The PKC's mandate is to produce long-term planning documents and to ensure that policies are effective and appropriate to attain long-term goals. To date, the PKC has produced the National Development Plan, monitored progress toward Latvia's long-term development plan (Latvia 2030), and carved out an active role in the decision-making process. The body can also be engaged in the early planning phase of new policies. It has been tasked with analysing transversal issues, such as evaluating the management of state-owned enterprises, demographics or income disparities.

47. However, the PKC is not well staffed enough to meet line ministries' demands and it has no financial capacity to engage outside expertise on specific substantive issues. Additional allocations of human resources would enable the government to build on success of the PKC, further consolidating its role in the policy-planning process and enabling it responds to ministries seeking to engage with the Centre in the early stages of policy planning. 


\section{Reinforcing regulatory impact assessment}

48. The regulatory impact assessment process is quite rigorous and all draft legislation has to undergo an assessment. Introducing new regulations requires justification and the process includes notably an assessment of the budgetary impact and compliance with the Latvia 2030 Strategy. In practice, though, the quality of analysis varies widely from detailed, evidence-based analysis to a simple pro forma cover sheet providing a brief summary of intent. The scope of investigation is often restricted to financial, budgetary, and administrative costs. Sustainability checks are not carried out and short-, medium- and long-term analyses are not required.

49. There is no threshold test for the preparation of more in-depth impact analyses of legislative and policy proposals with significant economic, social or environmental impacts. Such a test would help the public administration to prioritize resources better and to conduct more robust in-depth assessments for those proposed policies and laws that are likely to have the greatest costs and benefits for the economy.

50. In theory, government decision-making processes involve a large panel of stakeholders. Draft laws are published and non-governmental entities can provide inputs. In practice, however, the usual procedures for gathering cross-sectoral and expert input can be circumvented at the request of a minister, putting coordination and analytical quality at risk. In 2011 and 2012, a third of all issues before cabinet were fast-tracked, which appears excessive.

\section{Developing performance budgeting}

51. To ensure monitoring as well as promote control over budget use, performance budgeting is being developed at the programme level. Ministries and other state central institutions set goals, performance results and performance indicators characterising the degree of achievement for budget programmes and sub-programmes. Line ministries and other state central institutions submit quarterly reports on the budget execution process to the Ministry of Finance, including an overview of performed and non-performed actions and information about finance management improvement activities. As from the 2012 budget, the procedures for planning and reflecting operational level results and performance indicators in budgetary requests of ministries and other central state institutions have been improved. This information is included in the annual State Budget Law, thus provided to the parliament and public. Nevertheless, incentives for public bodies to conduct critical evaluations to identify fiscal space remain limited, suggesting evaluation capacities should be strengthened.

\section{Improving co-ordination in state-local relations}

52. Efficiency can be improved at all government levels. The Strategic Development Plan for 20102013 envisages greater centralisation and harmonisation as one means of increasing efficiency, including a reduction of the size of central government administration and the unification of personnel management, procurement systems and digitalisation of government services. On the other hand, the 2014 National Reform Programme envisages an enhanced role for local authorities. Combining the benefits of decentralisation with the efficiency aims of the central government is bound to be a challenge.

53. Reforms of local governments aim at both strengthening local democracy by involving the population in decision-making processes, and increasing efficiency and effectiveness by using updated methods of management. The principles of local government reforms in Latvia are based on the principles of the European Charter of Local Self-Government, the core of which being territorial reorganisation of administration. The aim of the reform, via amalgamation, has been to establish administrative territories (regions) capable of promoting economic development in association with local governments that would ensure high quality provision of services. This has resulted in a consolidation of municipal governments 
and an intermediate level of government which consists of five planning regions (indirectly elected regional governments). Yet, the disparity in local government sizes poses challenges in terms of capacity and resources. There is an efficiency argument for a further reduction of the number of local governments by means of merging. There could also be a case for an extra administrative subdivision (e.g. a region) for some sectors such as education, as some issues are too complex to be handled at the local level.

54. The functions of local governments in Latvia outstrip their financial resources. In principle, local governments enjoy a high degree of autonomy and perform a wide range of tasks (Box 2). But, in its 2011 report on Latvia's adherence to the European Charter of Local Self-Government, the Council of Europe concluded that local authorities have inadequate access to independently raised resources, and urged Latvia to increase local authorities' financial autonomy. The Latvian Association of Local and Regional Governments has persistently complained about the growing gap between actual revenue and the service obligations prescribed by law. In primary and secondary education, for example, the funding system changed, tying allocations to pupil enrolment. As mentioned above, this resulted in a rationalisation of the school network but also contributed to unequal access and quality at the local level (Terauda et al. 2014). The medium-term budget-planning process adopted in 2012 envisages a three-year budget cycle for local government, but for this to be effective and for stability to be restored to Latvian local finances an improved balance needs to be achieved between local spending responsibilities and local resources. One option is to increase property taxes perceived at the local level, but as noted above, local governments are reluctant to do so as they compete for taxpayers.

55. A better matching of local resources with obligations would still leave the problem of the equalisation system, which is implemented to balance substantially different tax capacities and service obligations of municipalities. Marked disparities in the level of socio-economic development of sub-central governments- notably between Riga and rural areas - imply extensive differences in tax revenues. An Equalisation Fund distributes resources between municipalities but the compensation system was set aside in 2009 because the central government was not able to guarantee payments to the local level in the difficult circumstances of the financial crisis. Financial equalisation can be justifiably regarded as one of the key instruments of regional development (in addition to the EU Structural Funds) and its functioning needs to become more efficient.

56. Almost all grants from the central government to the local level are earmarked. Such grants concern, notably, the remuneration of teachers and trainers, the salaries of medical staff, any increase in the minimum wage, investment projects, road maintenance and construction. The only non-earmarked grant is the equalisation transfer. In the longer term, the Latvian authorities may consider incorporating more financial incentives - for instance, by moving away from earmarked grants (which stimulate both federal and regional authorities to shift spending patterns in the direction of subsidised services) towards fixed non-earmarked grants, while ensuring that high-quality public services are provided.

\section{Box 2. State-local relations}

Tasks - The local government share of public expenditure is $27 \%$ (2010), slightly above the EU average of $24 \%$. Local authorities are responsible for education ( $43 \%$ of expenditures) as well as sharing provision of general public services (housing, utilities, recreation, culture, religion). Local governments have autonomous tasks, delegated tasks and legally mandated tasks. Each type of task is meant to be accompanied by a funding source.

Finance - Latvian municipalities rely mostly on tax revenues, grants from the central government and fines they are empowered to impose. The most important shared taxes are the individual income tax (around $80 \%$, negotiated annually) and the real estate tax (100\%). 
Fiscal rules - The fiscal rule for local governments focuses on the right of municipalities to borrow and issue guarantees. Annual borrowing cannot exceed $20 \%$ of the current budget revenues of a municipality, excluding earmarked grants and contributions to the Equalisation Fund. If local governments do not comply with their debt repayment obligations, the Treasury is entitled to apply sanctions and in case of financial problems, local governments are placed under supervision.

\section{Increasing administrative efficiency}

57. Bureaucracy and administrative inefficiency have plagued the Latvian economy. According to the OECD Product Market Regulation (PMR) indicators, businesses face a high degree of red tape, as regulatory procedures seem overly complex, notably in terms of permits and licenses. The administrative burden on start-ups, sole proprietors and corporation is above the OECD average. The objective as defined in the Public Administration Development Guidelines for 2014-20 is now to build an efficient, motivated, accessible and innovative public administration, providing citizens and businesses with quality and affordable public administration services, as well as reducing administrative obstacles and burdens.

\section{Improving human resource management}

58. Government wages have been very volatile in the past few years. From 2004 to 2008, public sector wages significantly outpaced private sector wages, to reach a level about $30 \%$ higher; but as a result of fiscal consolidation the gap narrowed substantially to around 10\% in 2010 (Figure 13). This fluctuation has not come without costs in terms of disruption and motivation of employees in the public sector, as evidenced by the fact that many high qualified specialists have left the government service.

Figure 13. Wages in the public sector have been volatile

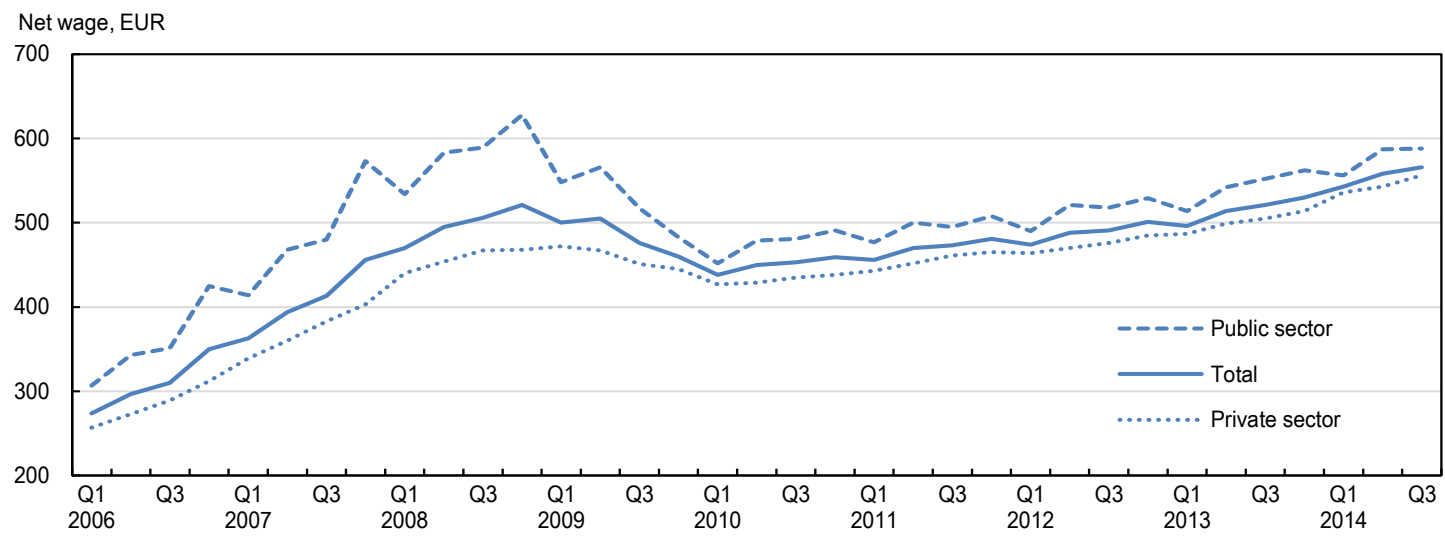

Source: Central Statistical Bureau of Latvia.

59. The wage cuts have left the public sector with a significant challenge in attracting, retaining and motivating talent. The lack of continuity in public pay, employment and productivity raise questions about how human resources management may be improved pointing to the need to avoid future boom-bust cycles in public resources and to look further at human resources (HR) practices. Increasing practices such as "flexible job descriptions", "realistic job previews", "regular appraisals" and "regular feedback on performance" would increase efficiency in the Latvian public sector (Lobanova and Ozola, 2013). Annual assessment of work performance is currently one of the criteria for determining wages and employees may receive a bonus once a year according to the results of annual assessment. Further developing resultsoriented pay and training would improve employee motivation, giving a motivational tool to heads of institutions and improving the retention of professionals in the public sector. Particular attention should be 
given to teacher remuneration, which is unlikely to be high enough to retain a quality and motivated workforce (OECD, 2014).

\section{Achieving greater efficiency in public procurement}

60. Achieving greater value for money from procurement spending is an important element in public sector efficiency (OECD 2013). This could be achieved by investing in innovative tools to streamline procurement procedures. For example, many central governments in the OECD have invested in eprocurement systems and almost all OECD member countries use framework agreements to take advantage of economies of scale. Latvia has made important progress in this area: the State Regional Development Agency passed framework agreements and central government institutions have since 2010 been obliged to use e-Catalogues based on these agreements. The State Agency for Internal Affairs and the State Agency for Defence Properties of the Ministry of Defence also act as central purchasing bodies. The government also modified regulations on centralised electronic procurement, widening the circle of buyers.

61. Ensuring that procedures are transparent is also key. The share of calls for tender published in the Official Journal as a percentage of total expenditure on public works, good and services was $87.2 \%$ in 2011, the highest percentage in the EU. Nevertheless, according to the 2013 Eurobarometer on businesses' attitudes towards corruption in the EU, 66\% of Latvian respondents consider that corruption is widespread in procurement managed by national authorities (vs. 56\% in the EU on average; Eurobarometer, 2013). The Procurement Supervision Bureau has noted cases in which procuring agencies failed to make documentation available to bidders, provided unclear or disproportionate requirements for bidders and subcontractors (for instance in terms of qualification). Risks also arise from the decentralised procurement of a range of standardised goods and services (such as internet services), despite the existence of a centralised e-procurement system.

62. A set of measures is in place to prevent conflicts of interest and corruption in public procurement. Amendments made to the Public Procurement Law in 2013 include an obligation for local governments to use centralised procurement for a range of services, stricter consequences for suppliers who fail to deliver according to procurement contracts, and the requirement to publish small procurement contracts online. Amendments to the Code of Administrative Violations also make it possible to sanction officials for procurement violations which do not amount to criminal offences. This progress needs to be consolidated by protecting the administration in charge of preventing and combatting corruption, the KNAB, from political interference, by strengthening the ability of the judiciary to handle corruption cases, and by providing practical guidance on conflicts of interest.

\section{Ensuring a transparent decision-making process}

63. The State Audit Office (SAO) plays an integral part in developing a fair and transparent decisionmaking process. With respect to external audit, the SAO is reputed to meet international standards and annually produces a large number of financial and performance audits of high quality. Its recommendations are generally followed up. However, in response to the financial crisis, the staff was reduced by $15 \%$ and there is some doubt as to whether it now has adequate resources. The SAO is financed from the budget and its budget request can be amended by the Cabinet of Ministers, possibly generating a conflict of interest. There is thus an on-going discussion on strengthening its budgetary independence.

64. Financial audits are performed annually and cover the correctness of the preparation of annual financial statements by all ministries and other central state institutions. Since this is the primary function of the SAO, a substantial share of its resources is channelled to this objective. Compliance and performance audits are planned in accordance with available resources. During 2013 a total of only 13 compliance or performance audits were performed as opposed to 28 financial audits. As from 2014, a 


\section{ECO/WKP(2015)72}

budget provision is being made for ad-hoc audits in cases where the SAO's expertise and opinion are needed to resolve contentious issues. This might improve the SAO's flexibility of response but still leaves funding below the pre-crisis level.

\section{Interfacing with the public}

65. Measures have been taken to improve the effectiveness of public administration processes by providing better access to public services for citizens and companies. The 2011 "E-governance Development Plan 2011-2013" aims at improving the operation and availability of the national information system, introducing complete electronic data and document transfer between institutions, consolidating and centralising national IT services. In 2013, the government approved the Information Society Development Guidelines 2014 - 2020 to further support the development of e-government. As a result, individuals and companies should have access to public administration services in a simpler, faster and remote manner. Public accessibility would also benefit from the introduction of the "one-stop agency" principle for the provision of state and local government services. This would improve local government service delivery by developing service access points, both personally and electronically and create common standards for local government services.

\section{Recommendations to improve public sector efficiency}

\section{Fiscal policy}

- Reinforce countercyclical liquidity buffers.

\section{Medium-term planning}

- $\quad$ Allocate adequate staff and resources to the Cross-Sectoral Coordination Centre.

- Introduce regular reporting on long-term spending trends and adequacy of social programmes such as pensions and healthcare.

\section{Institutional and administrative efficiency}

- Reinforce regulatory impact assessments by reducing fast-tracking, establishing specific sustainability checks and introducing threshold tests for the preparation of more in-depth analyses.

- Ensure that local governments are sufficiently resourced and autonomous by increasing their tax revenues, reducing the share of earmarked revenues, and improving the equalisation system.

- Modernise human resource management by further developing results-oriented pay.

- Strengthen the transparency of public procurement by ensuring the independence of institutions in charge of combating corruption and by providing practical guidance on conflicts of interest.

- Restore the funding of the State Audit Office to at least pre-crisis levels.

\section{Tax and benefit system}

- Strengthen efforts to tackle tax fraud and improve tax collection.

- Evaluate the current benefit system and make universal social benefits more targeted at low-income households.

- Gradually withdraw benefits targeted at low-income earners when they take up a job.

- Decrease the labour tax wedge for low-income earners.

- Raise additional revenues by increasing property and environmentally related taxes.

- Increase energy tax rates, making them depend on their relative carbon content.

- Phase out environmentally harmful subsidies.

- Continue to reduce the complexity of tax compliance. 


\section{Bibliography}

Baltic International Centre for Economic Policy Studies (BICEPS) (2014), Tax Reform in Latvia, Final Report.

Dreblow, E., M. Duwe, T. Wawer, L. Donat, E. Zelljadt, A. Ayres, I. Upatniece (2013), “Assessment of climate change policies in the context of the European Semester, Country Report: Latvia", Ecologic Institute, eclareon, June.

Eurobarometer (2011), Attitudes towards vocational education and training, Special Eurobarometer 369, European Commission, Brussels.

Eurobarometer (2013), Businesses' attitudes towards corruption in the EU, Flash Eurobarometer 374, European Commission, Brussels.

European Commission (2012), 2012 Ageing Report: Economic and budgetary projections for the EU27 Member States (2010-2060), EC, Brussels.

European Commission (2014a), "Assessment of the 2014 National Reform Programme and Stability Programme for Latvia", Commission staff working document, Brussels.

European Commission, (2014b), Innovation Union Scoreboard 2014, European Commission

European Commission (2014c), "2012 Update Report to the Study to quantify and analyse the VAT Gap in the EU-27 Member States", September 2014.

Kraan D-K, J. Wehner, J. Sheppard, V. Kostyleva and B. Duzler, (2009), "Budgeting in Latvia", OECD Journal on Budgeting, Vol. 2009/3.

Katsarova I. (2013), "The (low) absorption of EU Structural Funds", Library Briefing, Library of the European Parliament, 01/10/2013.

Lamine B. and E. Lohmuste, (2014), "Do the Baltics States need to tax passenger cars more”, ECFIN Country Focus, Vol. 12, Issue 11, November 2014.

Lobanova L.and I. Ozolina-Ozola (2013), "Comparative evaluation of the practical areas of human resource management in Lithuania and Latvia", Contemporary Issues in Business, Management and Education 201, Procedia - Social and Behavioral Sciences, 110(2014).

Ministry of Finance, Republic of Latvia (2014), PPP Policy, http://www.fm.gov.lv/en/s/ppp/ppp_policy/.

Norregaard J (2013), “Taxing Immovable Property Revenue Potential and Implementation Challenges”, IMF Working Paper WP/13/129.

OECD (2011), Taxation and Employment, The Taxation of Low-Income Workers, OECD Publishing.

OECD (2013), Principles for Integrity in Public Procurement: Progress in OECD Countries.

OECD (2014), Teacher remuneration in Latvia: an OECD perspective, OECD Publishing. 
Price R.W.R. (2010), “The Political Economy of Fiscal Consolidation”, Economics Department Working Papers No. 776.

Putniņš T.J. and Sauka, A. (2014), "Shadow Economy Index for the Baltic countries, 2009 - 2013", The Centre for Sustainable Business, SSE Riga.

PWC and World Bank (2014), Paying taxes 2015: The global Picture, World Bank, Washington.

Schneider F. (2013), "Size and Development of the Shadow Economy of 31 European and 5 other OECD Countries from 2003 to 2013: A Further Decline", http://www.econ.jku.at/members/Schneider/files/publications/2013/ShadEcEurope31_Jan2013.pdf

Sutherland, D., R. Price, I. Joumard and C. Nicq (2007), "Performance and Indicators for Public Spending Efficiency in Primary and Secondary Education", Economics Department Working Papers, No. 546, OECD Publishing.

Terauda V. A., A. Reetz, D. Jahn (2014), Latvia Report, Sustainable Governance Indicators, Bertelsmann Stiftung.

Traidase B. (2014), "Latvia`s Experience with Fiscal Adjustment”, Bank of Latvia, Eighth meeting of the Network of public finance economists in public administration, February 11, 2014.

World Bank (2014), “Who Is Unemployed, Inactive Or Needy? Assessing Post-Crisis Policy Options”, Scientific Research: Latvia.

World Economic Forum (WEF) (2014a), Global competitiveness Report, 2014 -2015

World Economic Forum (WEF) (2014b), The Europe 2020: Competitiveness Report, Building a More Competitive Europe

World Health Organisation and European Observatory of Health Systems and Policies (WHO and EOHSP) (2012), Latvia: Health System Review, Health systems in Transition, Vol. 14, No. 8, 2012. 